Original Article

\title{
PRODUCTIVITY ENHANCEMENT OF CORIANDRUM SATIVUM USING PLANT BIOLOGICALS
}

\author{
KAMAL JEET ${ }^{1,2}$, ALOK MALAVIYA ${ }^{3}$, ASHISH BALDI ${ }^{2,4 *}$ \\ ${ }^{1}$ Research Scholar, I. K. G. Punjab Technical University, Jalandhar, Punjab, India 144603, ${ }^{2}$ I. S. F. College of Pharmacy, Moga, Punjab, India \\ 142001, ${ }^{3}$ Applied and Industrial Biotechnology Laboratory (AIBL), Department of Life Sciences, CHRIST (Deemed to be University), Hosur \\ Road, Banglore, India 560029, 4Department of Pharmaceutical Sciences and Technology, Maharaja Ranjit Singh Punjab Technical \\ University, Bathinda, Punjab, India 151001 \\ Email: baldiashish@gmail.com
}

Received: 07 Mar 2020, Revised and Accepted: 30 Mar 2020

\section{ABSTRACT}

Objective: The present study was designed to investigate phytopromotional effects of Sebacina vermifera on economically and medicinally important aromatic plant - Coriandrum sativum (coriander).

Methods: Phytopromotional effects of Sebacina vermifera were evaluated on coriander, under greenhouse and field conditions. The evaluations were carried out with reference to emergence, growth promotion and quantitative as well as the qualitative composition of essential oil. Beside this the overall effects were comparatively assessed with the effects of (a) Phosphate solubilizing bacteria (Pseudomonas fluorescens) (b) Nitrogen-fixing bacteria (Azotobacter chroococcum) on coriander using same parameters.

Results: Mycorrhizal fungus (Sebacina vermifera) was observed with the most significant effect in all aspects viz. emergence, growth promotion and quantitative as well as the qualitative composition of essential oil.

Conclusion: Based upon the observations, Sebacina vermifera is highly recommended as a potential biological agent that could be applied for phytopromotional effects and economic cultivation of aromatic plants.

Keywords Azotobacter chroococcum, Coriander, Emergence, Essential oil, Pseudomonas fluorescens, Sebacina vermifera

(C) 2020 The Authors. Published by Innovare Academic Sciences Pvt Ltd. This is an open access article under the CC BY license (http://creativecommons.org/licenses/by/4.0/) DOI: http://dx.doi.org/10.22159/ijpps.2020v12i5.37374. Journal homepage: https://innovareacademics.in/journals/index.php/ijpps

\section{INTRODUCTION}

Coriander or cilantro (Coriandrum sativum L.) is a glabrous, aromatic and herbaceous annual plant belongs to family Apiaceae/ Umbelliferae, cultivated, since human civilization [1]. This plant is cultivated almost all over the world for culinary, medicine, perfumery and beverages uses [2]. Seeds of the plant contain up to $0.03-2.6 \%$ of the essential oil (EO) [3]. The major component of EO is linalool (40$82.9 \%$ of the oil), other components are $\alpha$-pinene, $\gamma$-terpinene, camphor, geranyl acetate, geraniol, borneol terpine-4-ol, $\alpha$-terpineol, $\beta$-citronellol and nerol and limonene [4]. These components are mainly responsible for the several medical uses of coriander, some of which include-antispasmodic and carminative applications [5-7], indigestion, against worms, rheumatism and pain in the joints [8]. It has also been recommended for dyspeptic complaints, loss of appetite, convulsion, insomnia and anxiety [9]. Some other beneficial applications of coriander include-antioxidant [10], anti-diabetic [11], anti-mutagenic [12], anti-lipidemic activities [13]

With the rapidly growing world population, we need to feed an additional 2 billion people by 2050 [14]. Under the pressure of more demand of feedstocks for a huge bioenergy market, the most important challenge will be to meet the nutritional and medical needs of a growing population by using the same amount of production area and water resources used today, while avoiding the pesticides and fertilizers of chemical origin. In such a challenging situation, we need to look for cost-effective and easy to produce solutions that can improve the crop productivity sustainably and in an eco-friendly way. The sustainable productivity can be achieved by suitable cultivar, balanced nutrition, water management and measure for protection etc. On the same line, currently, scientists are advocating for the application of plant biologicals as a sustainable and environmentally friendly solution to improve plant productivity. These biologicals help plants in multiple ways like improvement of soil health, improving water-holding, nutrient availability, resistance from biotic and abiotic stress etc. [15-18].
Mycorrhizal fungi are a well-known plant biological and mycorrhizal association is the most ancient symbiotic association between plants and soil fungi on this earth. This association covers more than $95 \%$ of terrestrial plant species. Mycorrhizal fungi efficiently provide several benefits to host plants such as-nutrient facilitation, protection from certain pathogens, drought stress tolerance, enhancement in essential activity (photosynthesis), vegetation and reproduction [19]. In addition, mycorrhiza is also known to ameliorate the effect of heavy metal toxicity. Mycorrhizal association may range from obligatory to mutualistic, and fungal symbiont may be restricted to get benefited with carbon source from the plant or may participate in other activities like mineralization of nutrients from non-living organic and inorganic sources [19]. Although many of mycorrhizal fungi are noncultivable axenically outside the host plant in pure culture [20], however $S$. vermifera belonging to the family Sebacinaceae is cultivable outside the host plant and can easily be maintained and manipulated under laboratory conditions [21]. Azotobacter and Phosphate solubilizing bacteria are another class of plant biologicals which are non-symbiotic, free-living bacteria capable of fixing nutrients, produce phytohormones and synthesize antibiotics provide a defense to plant against diseases [22, 23].

Pertaining to the beneficial effects of plant biologicals on plant productivity and the importance of $C$. sativum for household and medicinal applications, we planned this study to find out a plant biological assisted, environment-friendly solution to improve $C$. sativum productivity. In the present study, mycorrhizal fungi (Sebacina vermifera), nitrogen-fixing bacteria (Azotobacter chroococcum) and phosphate solubilizing bacteria (Pseudomonas fluorescens) were chosen as plant biologicals to investigate their effect on $C$. sativum productivity. This is an attempt to establish the mycorrhizal associated correlations between Sebacina vermifera and $C$. sativum, and at the same time comparison with the effects of nitrogen-fixing bacteria (A. chroococcum) and phosphate solubilizing bacteria ( $P$. fluorescens) on same plant will assist the dear peculiar specialty and specificity of $S$. vermifera. 


\section{MATERIALS AND METHODS}

\section{Plant biologicals}

Mycorrhizal fungi-Sebacina vermifera culture was procured from Prof. Virendra Swarup Bisaria, department of Biochemical Engineering and Biotechnology, Indian Institute of TechnologyDelhi, India. Culture of $S$. vermifera was maintained on slants containing a modified Kaefer-agar medium. The $\mathrm{pH}$ and temperature were maintained at 6.5 and $30 \pm 1{ }^{\circ} \mathrm{C}$, respectively. After incubation of $10 \mathrm{~d}$ slants were stored at $4{ }^{\circ} \mathrm{C}$ until further use [21]. The cultivation of fungus was done in $500 \mathrm{ml}$ Erlenmeyer flasks containing $100 \mathrm{ml}$ of Modified Kaefer liquid medium using gyratory shaker at $200 \mathrm{rpm}$ and $30 \pm 1{ }^{\circ} \mathrm{C}$. Fungal culture $(100 \mathrm{ml})$ after $8 \mathrm{~d}$ incubation was mixed with $1 \mathrm{ml}$ carboxymethylcellulose (CMC). CMC mixed culture $(25 \mathrm{ml})$ was then added to $75 \mathrm{~g}$ of sterilized talcum powder (Kumar et al. 2012). The formulated preparation was stored in airtight polythene bags and stored at room temperature until the experimentation. Azotobacter (Azotobacter chroococcum) and Phosphate solubilizing bacteria ( $P$. fluorescens) were commercially available biofertilizer preparations, supplied by Ganesh Agro Service Centre, Moga, Punjab, India.

\section{Host plant and experimental conditions}

Seeds of coriander (pb-sugandh variety) were collected from Punjab Agriculture University, Ludhiana, India, during the rabi season. Seeds of coriander were treated with $1 \%$ savlon Johnson and Johnson, USA) for 5 min followed by surface-sterilized using $70 \%$ (v/v) ethanol for $1 \mathrm{~min}$ and rinsed thrice with sterile doubledistilled water (SDDW). This was followed by treatment with $0.01 \%$ Bovistin (Saraswati Agro Chemicals Pvt. Ltd. India) for 2 min and rinsing with SDDW 4-5 times and soaked in distilled water for $24 \mathrm{~h}$. Prior to experimentation, to know the soil's chemical reserves, soil samples from pots of greenhouse and field were submitted to College of Agriculture (Department of Soil Sciences), Punjab Agricultural University, Ludhiana (Ref. no. 1807/70). The soil's chemical reserves belonging to pot and field are mentioned in table 1 . The pot study was conducted in the sterile soil under a greenhouse facility where the soil was autoclaved in cotton bags for $1 \mathrm{hr}$ at $121^{\circ} \mathrm{C}$ and placed to cool at room temperature; the whole process was repeated for 3 times after 24 $\mathrm{h}$ on 3 consecutive days. In the greenhouse, plants were grown in controlled environmental conditions maintained at $25 \pm 2{ }^{\circ} \mathrm{C}, 16 \mathrm{~h}$ light $/ 8$ $\mathrm{h}$ dark with light intensity 1,000 Lux and relative humidity $70 \%$. All field experiments were done in farms using Randomized complete block design (RCBD).

Table 1: Physical and chemical properties of soil

\begin{tabular}{|c|c|c|c|c|c|c|c|c|c|c|}
\hline Sample & $\mathbf{p H}$ & Electrical conductivity $(\mathrm{mmho} / \mathrm{cm})$ & $\mathrm{C}(\%)$ & $\begin{array}{l}\text { P } \\
\text { (kg/ha) }\end{array}$ & $\begin{array}{l}\text { K } \\
\text { (kg/ha) }\end{array}$ & $\begin{array}{l}\text { Fe } \\
\text { (kg/ha) }\end{array}$ & $\begin{array}{l}\text { Zn } \\
\text { (kg/ha) }\end{array}$ & $\begin{array}{l}\mathrm{Cu} \\
\text { (kg/ha) }\end{array}$ & $\begin{array}{l}\text { Mn } \\
\text { (kg/ha) }\end{array}$ & N (\%) \\
\hline Pot & 6.7 & 0.63 & 0.66 & 42.25 & 370.65 & 13.54 & 4.89 & 3.51 & 9.59 & 0.08 \\
\hline Field & 7.4 & 0.59 & 0.48 & 32.37 & 311.35 & 12.26 & 4.10 & 1.53 & 7.36 & 0.06 \\
\hline
\end{tabular}

Note: C-Carbon, P-Phosphorus, K-Potash, Fe-Ferrous, Zn-Zinc, Cu-Copper, Mn-Manganese, N-Nitrogen

\section{Treatments}

There were four treatment groups viz. Control (CON), A. chroococcum (AZOTO), P. fluorescens-Phosphate solubilizing bacteria (PSB), $S$. vermifera (SV). Where, CON group received simple treatment without any biologicals, AZOTO, PSB and SV groups received double treatment (soil as well as host seeds/plantlets) with different schemes. Treatment of seeds (for emergence studies) in respective groups except CON was carried out using paste of $1 \mathrm{~kg}$ biomass in $1 \mathrm{~L}$ of water (sufficient on 10 $\mathrm{kg}$ of seeds). The paste was applied uniformly on the seed surface then seeds were dried in the shade before sowing in pots or in the field.

Treatment of plantlets (for growth studies) was carried out by dipping roots in the paste of same composition used for seed treatment and sown immediately in pots or in the field.

Soil of pots was treated with AZOTO, PSB and SV by induction of $1 \mathrm{~kg}$ biomass in $19 \mathrm{~kg}$ of vermicompost and mixed with soil in the ratio of 60:40 (soil: treated vermicompost). Whereas, in field, treated vermicompost was spreaded as $60 \mathrm{~kg}$ treated vermicompost per acre. For standing plants, treatment (1 kg biomass in $19 \mathrm{~kg}$ of vermicompost) was carried out by applying drilling/drenching method after $8 \mathrm{w}$.

\section{Emergence studies in pots}

The pot study for each treatment group was carried out in 10 number of polythene pots of $2 \mathrm{~kg}$ capacity (total 100 seeds for each treatment groups). Before sowing the seeds, $3 / 4^{\text {th }}$ part of the pot was filled with treated soil, moistened with water. Following this, 10 healthy seeds of coriander were sown in individual pots containing moistened treated soil. This was followed by filling up the remaining $1 / 4^{\text {th }}$ of pot with treated dry soil, such that all the seeds were sown 2 $\mathrm{cm}$ below the soil surface in pot. Finally, water was sprinkled to moisten the dry soil added over the seeds. Soil was covered with straw to avoid the dryness and water was supplied daily to avoid drought stress.

\section{Emergence studies in the field}

The field study was conducted in the agricultural field where regular farming was done. Soil was made porous by several ploughings and disking to facilitate healthy root development. Total experimentation area was of $25 \times 37$ meter containing 24 plots of $4.95 \times 4.95$ meter each incorporated with well tilted and fine soil mixed with a predefined quantity of vermicompost and treatments. Each plot was separated with a buffering zone of more than 1 meter (fig. 1). Then 100 Seeds of each group were sown in each plot containing 10 rows and 10 columns, that single seed at a distance of $45 \mathrm{~cm}$ interspacing to next seed. Seeds were covered with soil layer in such that all seeds were covered $2 \mathrm{~cm}$ below the soil surface. Soil was moistened with a light spray of water. Soil was covered with straw to avoid the dryness and water was supplied daily to avoid drought stress.

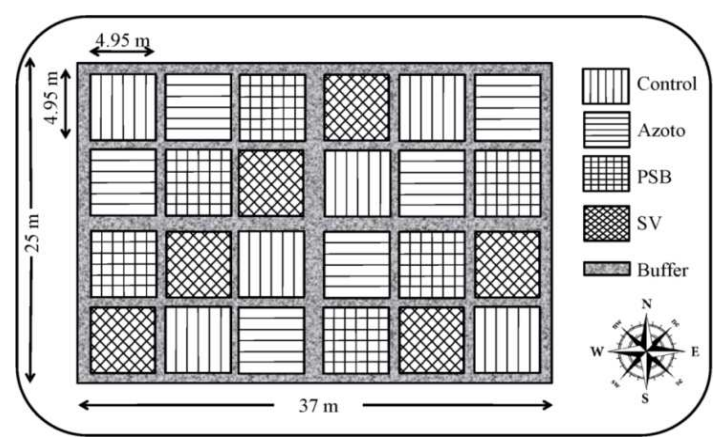

Fig. 1: Topology of field experiments (Randomized complete block design) 


\section{Emergence parameters}

Day of sowing was considered as zeroth day. Number of germinated seeds was counted daily and data were recorded after every $24 \mathrm{~h}$ until no more seed germinated. The seeds were considered germinated with the emergence of radicals to soil surface. Emergence of seeds was evaluated using the following parameters:

\section{Germination percentage}

Germination percentage is a measure of the overall viability of the accession of seeds and can approximate the number of seeds that will grow into plants when you plant them. At the end of the experiment, the number of seeds was added that germinated each day of the trial then divided by the total number of seeds that were taken in the test, and multiplied by 100 to calculate germination percentage [24]:

\section{Germination index}

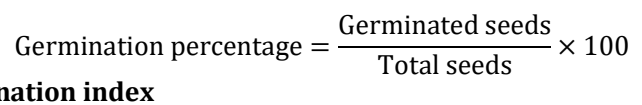

Germination index was calculated as described by AOSA [25] as the following formula:

$$
\mathrm{GI}=\frac{\text { No. of germinated seed }}{\text { Days of the first count }}+---+\frac{\text { No. of germinated seed }}{\text { Days of final count }}
$$

\section{Mean germination time}

Mean germination time was calculated in days by using the following equation $[26,27]$ :

$$
\operatorname{MGT}=\frac{\Sigma \mathrm{D} \times \mathrm{n}}{\Sigma \mathrm{n}}
$$

Where $\mathrm{n}$ is the number of seeds germinated on day $\mathrm{D}$, and $\mathrm{D}$ is the number of days counted from the beginning of germination.

\section{$\mathbf{T}_{\mathbf{5 0}}$ of germination}

The time to $50 \%$ germination $\left(\mathrm{T}_{50}\right)$ was calculated by using following formula [28-30]:

$$
\mathrm{T} 50=\mathrm{t}_{\mathrm{i}}+\frac{\left[\frac{\mathrm{N}}{2}-\mathrm{n}_{\mathrm{i}}\right]\left(\mathrm{t}_{\mathrm{j}}-\mathrm{t}_{\mathrm{i}}\right)}{\mathrm{n}_{\mathrm{j}}-\mathrm{n}_{\mathrm{i}}}
$$

Where $\mathrm{N}$ is the final number of germinated seeds and $n_{i}, n_{j}$ are cumulative number of seeds germinated by adjacent counts at times $\mathrm{t}_{\mathrm{i}}$ and $\mathrm{t}_{\mathrm{j}}$ where $\mathrm{n}_{\mathrm{i}}<\mathrm{N} / 2<\mathrm{n}_{\mathrm{j}}$.

\section{Seed vigour}

It is expressed as the mean of the total length of the seedlings [31]:

$$
\text { Seed vigour }=\frac{\Sigma \ln }{\mathrm{n}}
$$

Where $\mathrm{l}=$ the length of seedling; $\mathrm{n}=$ total number of seedlings.

\section{Vigour index}

Vigour index was calculated at the time of the final count. For this, seedling vigour of 6 randomly selected seedlings were measured $(\mathrm{mm})$ then multiplied by germination percentage (\%) [32]:

$$
\mathrm{VI}=\mathrm{SV} \times \mathrm{GP}
$$

Where SV = Seed vigour; GP = germination percentage.

\section{Growth studies in pots}

The young and healthy $20 \mathrm{~d}$ old plantlets of similar size and in the same development stage were taken for the growth study. In pot study, treated plants were planted on a hard substratum of treated soil. For each set, the total numbers of test pots planted were 100 . Study was carried using plastic pots of $10 \mathrm{~kg}$ capacity. In each pot, 1 healthy plants of coriander were transplanted and soil was moistened enough to avoid the drought stress. All the pots were watered regularly. Plants were uprooted at 30 d interval i.e. 30, 60, 90, $120 \mathrm{~d}$ after transplantation (DAT) for growth evaluations. Sample size from each replicate was 6 individual plants.

\section{Growth studies in fields}

The young and healthy treated plantlets of $20 \mathrm{~d}$ and of similar size and in the same development stage were taken and sown in treated soil, to carry the growth study. All experiments were done in six replicates (sample size was 6 from each replicate) using complete randomized design in pot and randomized complete block design in the field. Field topography was the same as used for emergence study (fig. 1). Then 100 plants of each group were sown in each plot containing 10 rows and 10 columns, that single plant at a distance of $45 \mathrm{~cm}$ interspacing to the next plant. After transplantation, the whole field was irrigated with water. Plants were uprooted at $30 \mathrm{~d}$ interval i.e. 30, 60, 90, 120 DAT for growth evaluations. Sample size from each replicate was 6 individual plants.

\section{Growth parameters}

Day of the plantation was considered a zeroth day. For the analysis of plant growth parameters, plants were randomly uprooted at the regular interval of $30 \mathrm{~d}$; final harvesting was done on 120 DAT. Before uprooting the plants, the field and pots were moistened enough so that the whole plants could be uprooted easily. Uprooted plants were washed under a slow stream of water. Length was measured carefully with the ruler; dry weights were recorded by drying the samples in an oven at $60{ }^{\circ} \mathrm{C}$ for $48 \mathrm{~h}$. Following parameters were evaluated for individual uprooted plants:

a) Total plant length (root+shoot)

b) Total fresh weight of plant (root+shoot)

c) Total dry weight of the plant (root+shoot)

\section{Root colonization study}

Samples of fine roots from treated seedlings of $C$. sativum at an interval of $30 \mathrm{~d}$ i.e. 30, 60, 90, 120 DAT were collected and washed thoroughly under a slow stream of distilled water. Collected roots were cut into small segments (approx. $1 \mathrm{~cm}$ ) and boiled with $\mathrm{KOH}$ $(10 \%)$ for $15 \mathrm{~min}$ to soften the tissue. Then the segments were neutralized with $1 \mathrm{~N} \mathrm{HCl}$ for 3-4 min, and repeatedly washed with distilled water to make it neutral. The segments then stained with $0.5 \%$ trypan blue overnight and mounted in lactoglycerol blue solution [33] (slightly modified). Random segments were picked and placed on a glass slide and examined under a light microscope at the magnification of $10 x-40 x$. Experiment was done in six replicate and sample size was six plants from each replicate. Ten segments from each plant were taken and root colonization was assessed using the following formula [34]:

$$
\text { Percentage colonization }=\frac{\text { Number of root segments colonized }}{\text { Number of total segments examined }} \times 100
$$

\section{Phytochemical analysis}

\section{Oil extraction}

Sample of seeds was collected from well-grown healthy plants (120 $\mathrm{d}$ older) of each group and dried at room temperature. Dried samples were grounded in a blender. The extractions of grounded seeds were done by hydro-distillation using a Clevenger apparatus for $4 \mathrm{~h}$. The oil samples were collected in the airtight container and stored at $4{ }^{\circ} \mathrm{C}$ until further analysis.

\section{Gas chromatography-mass spectrometry}

GC-MS analyses were carried out on a gas chromatograph Thermo trace 1300 GC coupled to a Thermo TSQ 8000 mass spectrometer with electron impact ionization method. Ion source temperature was $230{ }^{\circ} \mathrm{C}$. A TG-5MS capillary column ( $30 \mathrm{~m} \times 0.25 \mathrm{~mm}, 0.25 \mu \mathrm{m}$ film thickness) was used. The column temperature was programmed to rise from $50{ }^{\circ} \mathrm{C}$ ( $2 \mathrm{~min}$ ) to $280{ }^{\circ} \mathrm{C}$ at the rate of $10{ }^{\circ} \mathrm{C} / \mathrm{min}$. The $\mathrm{S} / \mathrm{SL}$ injector's temperature was maintained at $250^{\circ} \mathrm{C}$, and the injection volume was 1.0 $\mu \mathrm{L}$. The MS transfer line temperature was maintained at $280{ }^{\circ} \mathrm{C}$. The carrier gas was helium with a flow rate $1 \mathrm{ml} \mathrm{min}^{-1}$ and the mass range was $50-500 \mathrm{~m} / \mathrm{z}$. EO components were identified by comparison spectral data to those from mass spectra stored in the National Institute of Standards and Technology (NIST) spectral library. The percentage peak area of the corresponding component was taken as content concentration without using correction factors [35]. 


\section{Statistical analysis}

All experiments were performed in six replicates (Sample size was 6 from each replicate except GCMS). The data were expressed as mean \pm standard deviation (SD). The data of emergence, yield of EO and composition of various EO components were analyzed by oneway analysis of variance (ANOVA) followed by Tukey's post hoc test to compare means at the significance level $p<0.05$. Growth data were analyzed used two-way ANOVA followed by Bonferroni post-test for multiple comparisons of means at the significance level $p<0.05$. All statistical analyses were performed using the GraphPad Prism v6 software package.

\section{RESULTS}

\section{Root colonization study}

The presence of fungal hyphae confirms the positive colonized association between tested plant and S. vermifera under both conditions i.e. pots under greenhouse and field conditions. Further, there was a variation in overall colonization percentage of pots and field. Colonization percentage was found lowest at 30 DAT (pot$21.43 \%$; field-17.13\%), which gradually increased at 60 DAT (pot43.18\%; field-25.28\%) and 90 DAT (pot-65.21\%; field-42.12\%). The highest colonization percentage was recorded at 120 DAT (pot87.65\%; field-81.75\%) (table 2).

\section{Emergence studies}

Emergence studies on coriander seeds were observed for $20 \mathrm{~d}$ from the day of sowing of seeds. Different analytical traits viz. germination percentage, mean germination time, germination index, $\mathrm{T}_{50}$ of germination, seedling vigour and vigour index were investigated carefully. All traits revealed that different treatments exert significant effects on the emergence of seeds under both pot as well as field conditions (table 3,4).

\section{Emergence studies under pot conditions}

Results of emergence studies under pot conditions have been presented in table 3. Data shows that SV, AZOTO and PSB outperformed CON with respect to all the measured emergence parameters. Among the tested plant biologicals, SV showed best results followed by AZOTO and PSB, respectively. As compared to CON, germination percentage, germination index, seedling vigour and vigour index for SV were improved by $97.9 \%, 118.9 \%, 81 \%$ and $258 \%$, respectively.

For PSB, these traits were improved by $91.8 \%, 102 \%, 46.5 \%$ and $181 \%$, respectively, while for AZOTO, these traits were improved by $34.6 \%, 39 \%, 32.7 \%$ and $78.8 \%$, respectively. On the other hand, mean germination time was reduced by $9.8 \%, 5.4 \%$ and $3.7 \%$, respectively, for SV, PSB and AZOTO. Similarly, $\mathrm{T}_{50}$ germination was reduced by $9.5 \%, 3.7 \%$ and $2.8 \%$ for SV, AZOTO and PSB, respectively (table 3).

Table 2: Colonization percentage of Sebacina vermifera with coriander roots at different time periods in pot and field trials

\begin{tabular}{lll}
\hline Harvesting & Pot & Field \\
\hline 30 DAT & $21.43 \pm 0.71$ & $17.13 \pm 0.38$ \\
60 DAT & $43.18 \pm 1.38$ & $25.28 \pm 0.85$ \\
90 DAT & $65.21 \pm 1.74$ & $42.12 \pm 1.32$ \\
120 DAT & $87.65 \pm 3.09$ & $81.75 \pm 2.23$ \\
\hline
\end{tabular}

Root colonization (\%) of Sebacina vermifera treated plants: data expressed as mean \pm SD of six replicates. CON-Normal control; SV-S. vermifera; DATDay after transplantation.

Table 3: Effects of various treatments on coriander seeds under pot trials

\begin{tabular}{llll}
\hline Parameters & CON & AZOTO & PSB \\
\hline Germination percentage & $49.00 \pm 2.65$ & $66.00 \pm 2.00^{\mathrm{a}}$ & $94.00 \pm 1.00^{\mathrm{a}, \mathrm{b}}$ \\
Mean germination time & $14.39 \pm 1.10$ & $13.85 \pm 0.63$ & $13.60 \pm 0.76$ \\
Germination index & $3.48 \pm 0.34$ & $4.85 \pm 0.61^{\mathrm{a}}$ & $7.03 \pm 0.25^{\mathrm{a}, \mathrm{b}}$ \\
$\mathrm{T}_{50}$ germination & $15.41 \pm 0.70$ & $14.97 \pm 0.63$ & $14.84 \pm 0.65$ \\
Seedling vigour $(\mathrm{mm})$ & $58.00 \pm 1.53$ & $77.00 \pm 2.52^{\mathrm{a}}$ & $85.00 \pm 2.00^{\mathrm{a}, \mathrm{b}}$ \\
Vigour index $(\mathrm{mm})$ & $2842.00 \pm 223.70$ & $5082.00 \pm 320.75^{\mathrm{a}}$ & $7990.00 \pm 160.66^{\mathrm{a}, \mathrm{b}}$ \\
\hline
\end{tabular}

Emergence response of seeds to various treatments in pots trials: data expressed as mean \pm SD of six replicates. Superscripts with different letters (ac) within the same row represent significance level as $p^{\mathrm{a}}<0.05 \mathrm{v} / \mathrm{s}$ Con; $p^{\mathrm{b}}<0.05 \mathrm{v} / \mathrm{s}$ AZOTO; $p^{\mathrm{c}}<0.05$ PSB; CON-Normal control; AZOTO-Azotobacter; PSB-Phosphate solubilizing bacteria; SV-S. vermifera

\section{Emergence studies in the field}

The relative effect of all three biologicals (SV, AZOTO, PSB) during field study were in alignment to what we observed during pot studies. Among all the four tested groups (CON, SV, AZOTO, PSB) under field conditions, two treatment groups viz. SV, PSB and AZOTO significantly altered the emergence profile of all the traits. Treatment with SV resulted in maximum effect followed by PSB and AZOTO, on various parameters studied during emergence study in the field. Here, germination percentage, germination index, seedling vigour and vigour index for SV were improved by $97.7 \%, 129 \%, 54.5 \%$ and $205.5 \%$, respectively, when compared with CON. Similarly, with PSB, these traits were improved by $86 \%, 111 \%, 27 \%$ and $137 \%$, respectively. With AZOTO, respective improvement of mentioned parameters was $45 \%, 54.6 \%, 12.7 \%$ and $63.9 \%$. On the other hand, mean germination time was reduced by $13.8 \%, 11.6 \%$ and $5.8 \%$ for SV, PSB and AZOTO, respectively. Similarly, $\mathrm{T}_{50}$ germination was reduced by $7.5 \%, 3 \%$ and $2 \%$ for SV, PSB and AZOTO respectively (table 4).

\section{Growth studies}

Effect of tested plant biologicals on the growth profile of coriander was also evaluated to understand their role in the physiological development of coriander plants. Growth profiles were measured in terms of total plant length, total fresh weight, and total dry weight. All the treatments as mentioned in the materials and methods, were applied respectively to soil and plants. Statistical analysis of observed effects was also established by using Two-way ANOVA. Finally, it was found that all the treatments resulted in significant growth enhancement both in pot and in field conditions.

\section{Growth studies in pots}

During pot studies, all three treatments (SV, PSB and AZOTO) showed a positive effect when compared with CON experiments. SV was found to have most prominent and significantly high stimulatory effect on plant growth, which was followed by PSB and AZOTO, respectively (fig. $2,3 a, c, e)$. Relative growth rates of plant for all three treatments i.e. SV, PSB, AZOTO showed better results when compared with CON experiments. Growth rates of treated plants were found to be in increasing order at $30 \mathrm{DAT}, 60 \mathrm{DAT}$ and $90 \mathrm{DAT}$, whereas growth rate was found to be declined after 90 DAT to 120 DAT (fig. 3b,d,f). As compared to CON, SV treatment resulted in a maximum of $99 \%, 154 \%$ and $140 \%$ improvement in total plant length, fresh weight and dry weight, respectively. PSB improved these traits by $50 \%, 94 \%, 92 \%$, respectively, whereas improvement with AZOTO was $37.6 \%$, 89\%, $86.5 \%$, respectively, for the same traits (fig. 3 ). 
Baldi et al.

Table 4: Effects of various treatments on coriander seeds under field trials

\begin{tabular}{llll}
\hline Parameters & CON & AZOTO & PSB \\
\hline Germination percentage & $44.00 \pm 2.00$ & $64.00 \pm 2.52^{\mathrm{a}}$ & $82.00 \pm 2.52^{\mathrm{a}, \mathrm{b}}$ \\
Mean germination time & $15.43 \pm 0.59$ & $14.53 \pm 0.86$ & $13.63 \pm 0.50^{\mathrm{a}}$ \\
Germination index & $2.91 \pm 0.51$ & $4.50 \pm 0.57^{\mathrm{a}}$ & $6.14 \pm 0.17^{\mathrm{a}, \mathrm{b}}$ \\
t50 germination & $15.40 \pm 0.23$ & $15.03 \pm 0.11$ & $14.88 \pm 0.51$ \\
Seedling vigour (mm) & $55.00 \pm 2.08$ & $62.00 \pm 2.00^{\mathrm{a}}$ & $70.00 \pm 2.00^{\mathrm{a}, \mathrm{b}}$ \\
Vigour index (mm) & $2420.00 \pm 197.36$ & $3968.00 \pm 284.76^{\mathrm{a},}$ & $5740.00 \pm 340.78^{\mathrm{a}, \mathrm{b}}$ \\
\hline
\end{tabular}

Emergence response of seeds to various treatments in field trials: data expressed as mean $\pm S D$ of six replicates. Superscripts with different letters (ac) within the same row represent significance level as $p^{\mathrm{a}}<0.05 \mathrm{v} / \mathrm{s}$ CON; $p^{\mathrm{b}}<0.05 \mathrm{v} / \mathrm{s}$ AZOTO; $p^{\mathrm{c}}<0.05$ PSB; CON-Normal control; AZOTO-Azotobacter; PSB-Phosphate solubilizing bacteria; SV-S. vermifera

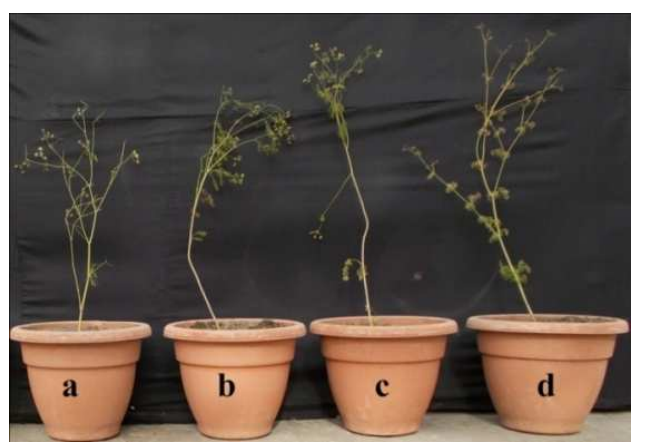

Fig. 2: Plants under pot trials at 120 DAT (a) Control (b) Azotobacter (c) Phosphate solubilizing bacteria (d) S. vermifera

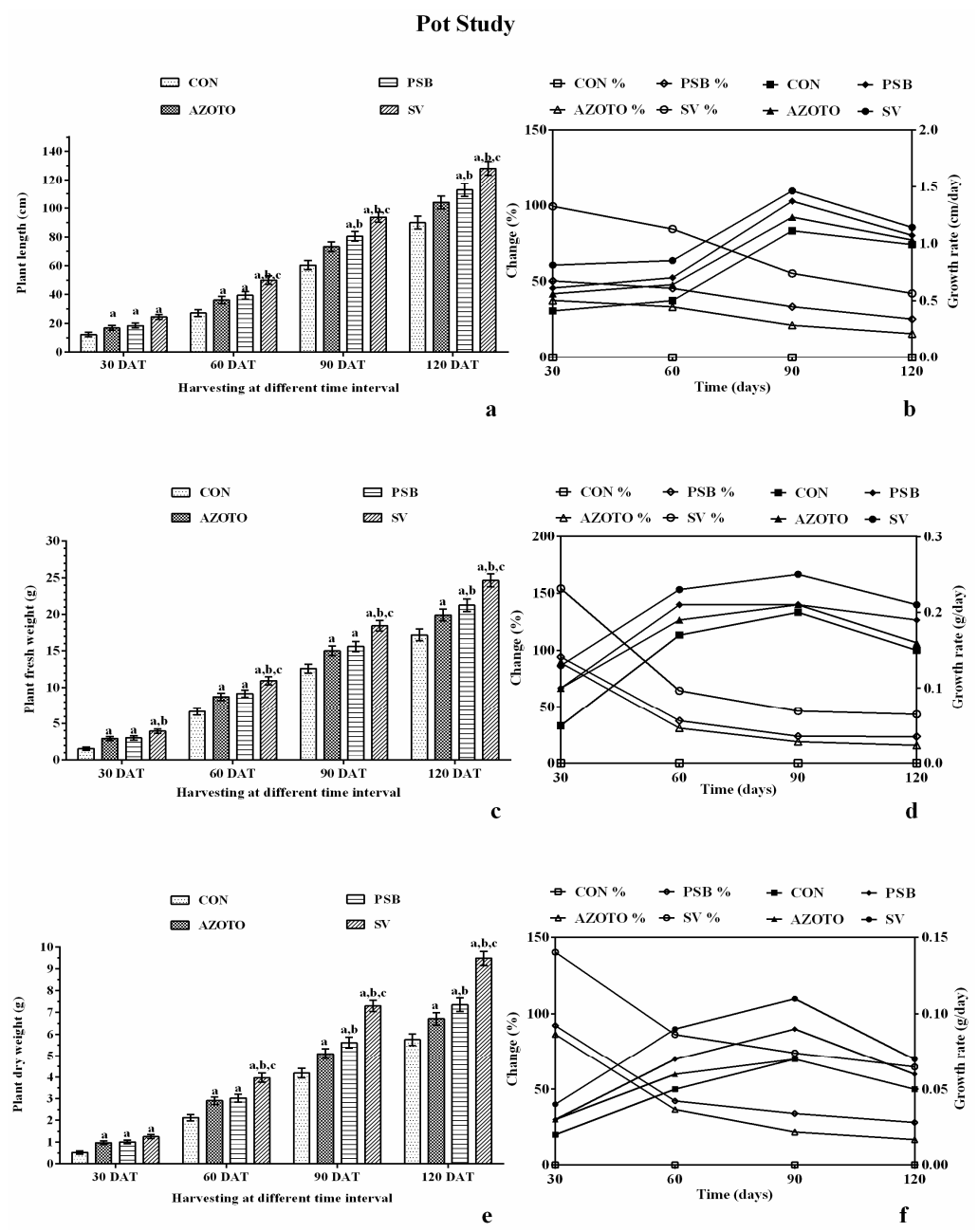

Fig. 3: Effect of treatments on (a, b) Total length of plants (c, d) the Total fresh weight of plants (e, f) Total dry weight of plants under pot conditions; data expressed as mean \pm SD of six replicates. Superscripts with different letters (a-c) within the same harvesting group represent significance level as $p^{a}<0.05 \mathrm{v} / \mathrm{s}$ CON; $p^{b}<0.05 \mathrm{v} / \mathrm{s} \mathrm{AZOTO;} \boldsymbol{p}^{c}<0.05 \mathrm{v} / \mathrm{s}$ PSB; CON-Normal control; AZOTO-Azotobacter; PSBPhosphate solubilizing bacteria; SV-S. vermifera 


\section{Growth studies in fields}

Once we got encouraging results at pot scale, we extended this study to field scale to validate the applicability of lab-scale data in actual field conditions. Similar growth studies were done with experiments done in field conditions. Data from field studies corelated well with pot scale experimental data. Again, all three treatments (SV, PSB and AZOTO) showed significantly high effect when compared with CON group experiments. However, best results were observed in experiments with $\mathrm{SV}$, which was followed by PSB and AZOTO, respectively (fig. 4, 5a,c,e). Similar trends were observed in the relative growth rate. Growth rates of treated plants were found to be in increasing order at $30 \mathrm{DAT}, 60 \mathrm{DAT}$ and 90 DAT, whereas growth rate was found to be declined after 90 DAT to 120 DAT (fig. $5 \mathrm{~b}, \mathrm{~d}, \mathrm{f}$ ). As compared to CON, SV treatment resulted in a maximum of $95.6 \%, 133 \%$ and $136 \%$ improvement in total plant length, fresh weight and dry weight, respectively. PSB improved these traits by $47.8 \%, 93 \%, 92 \%$, respectively, whereas improvement with AZOTO was $36 \%, 88 \%, 86 \%$, respectively, for the same traits (fig. 5).

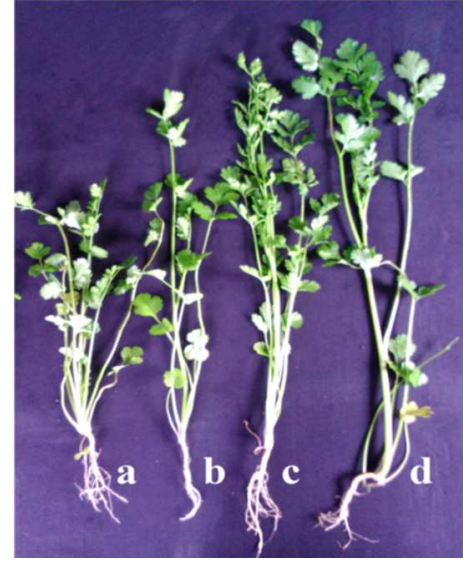

Fig. 4: Plants under field trials at 60 DAT (a) Control (b) Azotobacter (c) Phosphate solubilizing bacteria (d) S. vermifera

Field Study
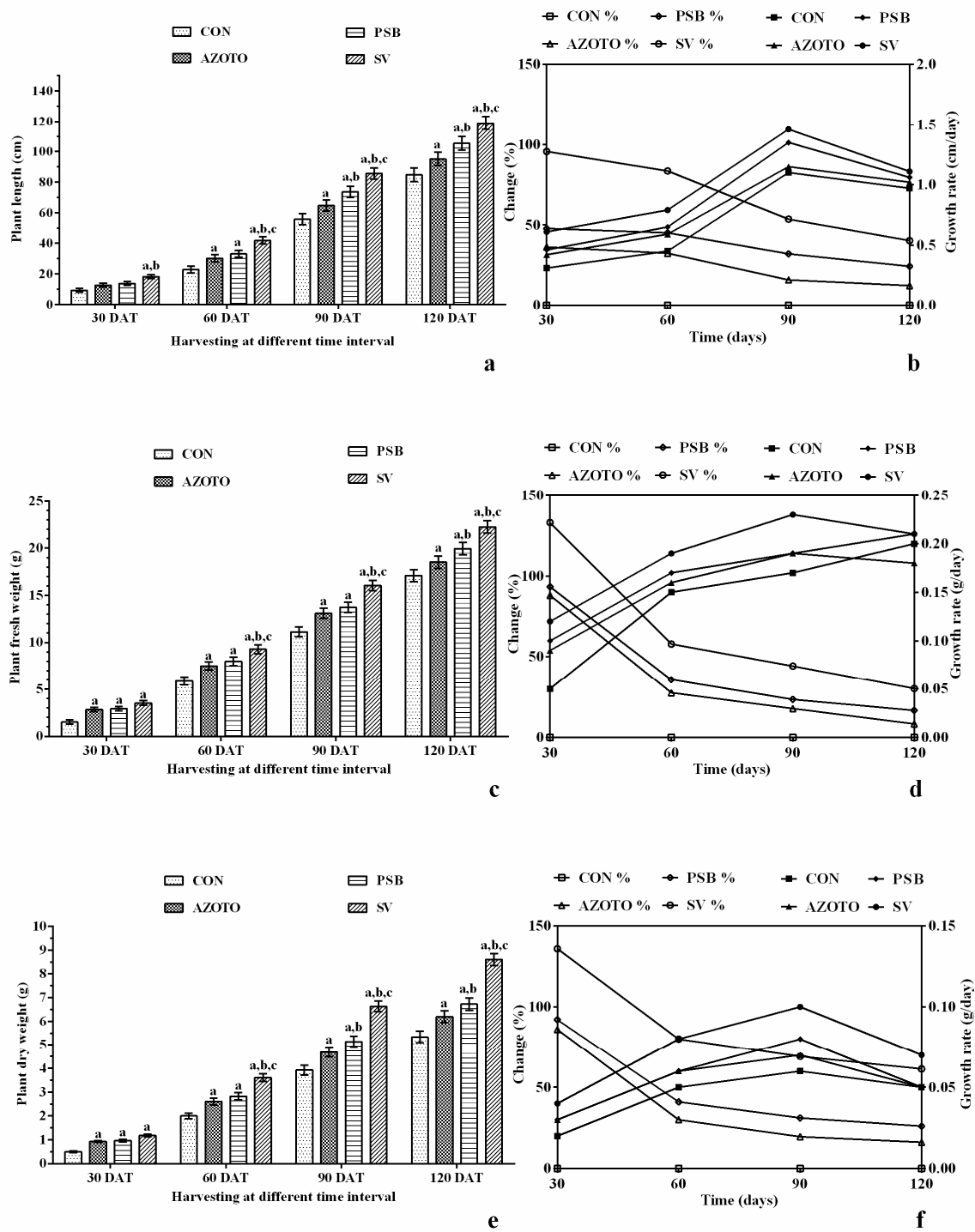

Fig. 5: Effect of treatments on (a, b) Total length of plants (c, d) the Total fresh weight of plants (e, f) Total dry weight of plants under field conditions; data expressed as mean $\pm \mathrm{SD}$ of six replicates. Superscripts with different letters $(\mathrm{a}-\mathrm{c})$ within the same harvesting group represent significance level as $p^{a}<0.05 \mathrm{v} / \mathrm{s}$ CON; $p^{b}<0.05 \mathrm{v} / \mathrm{s}$ AZOTO; $\boldsymbol{p}^{c}<0.05 \mathrm{v} / \mathrm{s}$ PSB; CON-Normal control; AZOTO-Azotobacter; PSBPhosphate solubilizing bacteria; SV-S. vermifera 
Table 5: Effect of different treatments on the composition of various EO components of coriander seeds grown in pots under greenhouse conditions

\begin{tabular}{|c|c|c|c|c|c|}
\hline \multirow[t]{2}{*}{ RT } & \multirow[t]{2}{*}{ Individual components } & \multicolumn{4}{|l|}{ Pot } \\
\hline & & CON & AZOTO & PSB & SV \\
\hline 6.75 & $\alpha$-Pinene & $15.32 \pm 0.87$ & $13.02 \pm 0.92$ & $12.54 \pm 0.87^{a}$ & $25.53 \pm 1.07 \mathrm{a}, \mathrm{b}, \mathrm{c}$ \\
\hline 7.6 & $\beta$-pienene & $2.27 \pm 0.43$ & $1.57 \pm 0.33$ & $1.17 \pm 0.19^{\mathrm{a}}$ & $3.77 \pm 0.14^{\mathrm{a}, \mathrm{b}, \mathrm{c}}$ \\
\hline 7.81 & $\alpha$-Myrcene & $0.99 \pm 0.24$ & $0.60 \pm 0.17$ & $0.75 \pm 0.22$ & $1.15 \pm 0.18^{b}$ \\
\hline 8.5 & o-Cymene & $0.62 \pm 0.15$ & $0.67 \pm 0.07$ & $0.85 \pm 0.11$ & $0.86 \pm 0.09$ \\
\hline 8.7 & D $\neg$ Limonene & $0.73 \pm 0.12$ & $2.51 \pm 0.16^{\mathrm{a}}$ & $0.66 \pm 0.08^{b}$ & $0.72 \pm 0.09 \mathrm{~b}$ \\
\hline 9.31 & $\Upsilon$-Terpinene & $1.47 \pm 0.26$ & $1.66 \pm 0.09$ & $0.49 \pm 0.07^{\mathrm{a}, \mathrm{b}}$ & $1.74 \pm 0.47^{c}$ \\
\hline 9.52 & trans-Linalool oxide (furanoid) & - & - & $0.94 \pm 0.23$ & - \\
\hline 9.67 & 1-Octanol & $1.13 \pm 0.17$ & $0.36 \pm 0.11$ & - & - \\
\hline 10.23 & Linalool & $49.74 \pm 1.16$ & $51.03 \pm 0.29$ & $52.62 \pm 0.96^{a}$ & $55.61 \pm 0.72^{\mathrm{a}, \mathrm{b}, \mathrm{c}}$ \\
\hline 11.14 & Citronellal & $0.96 \pm 0.23$ & $0.97 \pm 0.10$ & - & $0.62 \pm 0.06$ \\
\hline 11.15 & Nerol & - & - & $1.01 \pm 0.17$ & - \\
\hline 11.61 & Borneol & $0.49 \pm 0.14$ & $0.53 \pm 0.08$ & $0.71 \pm 0.04$ & - \\
\hline 12.06 & $\alpha$-Terpineol & - & $0.62 \pm 0.17$ & $1.29 \pm 0.13$ & - \\
\hline 12.07 & Methyl chavicol & $0.88 \pm 0.08$ & - & - & - \\
\hline 12.2 & D-verbenone & - & - & $0.68 \pm 0.08$ & - \\
\hline 12.22 & Decanal & $0.53 \pm 0.11$ & $0.53 \pm 0.11$ & - & $0.44 \pm 0.02$ \\
\hline 12.78 & Citronellol & $1.39 \pm 0.14$ & - & $1.36 \pm 0.22$ & $1.00 \pm 0.18$ \\
\hline 12.75 & 1-Cyclohexene-1-carboxaldehyde,2,66-trimethyl- & - & $2.79 \pm 0.13$ & - & - \\
\hline 13.28 & Geraniol & $1.71 \pm 0.11$ & $1.28 \pm 0.05^{\mathrm{a}}$ & $2.55 \pm 0.15^{\mathrm{a}, \mathrm{b}}$ & $1.17 \pm 0.06^{\mathrm{a}, \mathrm{c}}$ \\
\hline 13.83 & Anethole & $2.20 \pm 0.88$ & $0.97 \pm 0.11$ & $0.46 \pm 0.17^{\mathrm{a}}$ & - \\
\hline 14.12 & Thymol & $0.84 \pm 0.10$ & $0.48 \pm 0.16$ & $0.39 \pm 0.17 \mathrm{a}$ & - \\
\hline 14.27 & Undecanal & $0.51 \pm 0.18$ & $0.48 \pm 0.14$ & $0.58 \pm 0.33$ & - \\
\hline 15.18 & Citronellyl acetate & $1.03 \pm 0.18$ & $0.66 \pm 0.13$ & $1.42 \pm 0.43^{b}$ & $0.54 \pm 0.10^{c}$ \\
\hline 15.78 & Geranyl acetate & $16.39 \pm 1.48$ & $8.82 \pm 0.43^{\mathrm{a}}$ & $17.11 \pm 0.56^{b}$ & $6.86 \pm 0.65^{\mathrm{a}, \mathrm{c}}$ \\
\hline 16.22 & Dodecanal & - & - & $0.36 \pm 0.11$ & - \\
\hline 16.85 & Caryophyllene & $0.43 \pm 0.10$ & - & $0.43 \pm 0.04$ & - \\
\hline 17.23 & 2-Dodecenal & $0.35 \pm 0.07$ & - & $0.38 \pm 0.13$ & - \\
\hline 17.84 & $\alpha$-guaiene & - & $1.28 \pm 0.04$ & - & - \\
\hline 18.05 & Longifolene & - & $5.80 \pm 0.71$ & - & - \\
\hline 18.18 & $\alpha$-Humulene & - & $1.20 \pm 0.12$ & - & - \\
\hline 18.71 & Epiglobulol & - & $1.51 \pm 0.16$ & - & - \\
\hline 20.68 & Humalane-1,6-dien-3-ol & - & $0.67 \pm 0.10$ & - & - \\
\hline 20.72 & Tetradecanal & - & - & $0.38 \pm 0.24$ & - \\
\hline 22.34 & Tetradecanoic acid & - & - & $0.88 \pm 0.60$ & - \\
\hline \multicolumn{2}{|c|}{ Monoterpene hydrocarbons } & $21.40 \pm 2.07$ & $27.11 \pm 2.47^{\mathrm{a}}$ & $16.45 \pm 1.53^{\mathrm{b}}$ & $33.77 \pm 2.03^{\mathrm{a}, \mathrm{b}, \mathrm{c}}$ \\
\hline \multicolumn{2}{|c|}{ Monoterpene alcohols } & $57.56 \pm 2.68$ & $56.96 \pm 1.06$ & $59.99 \pm 1.83$ & $57.78 \pm 0.96$ \\
\hline \multicolumn{2}{|c|}{ Monoterpene ethers } & - & - & $0.94 \pm 0.23$ & - \\
\hline \multicolumn{2}{|c|}{ Monoterpene aldehydes } & $2.35 \pm 0.59$ & $4.76 \pm 0.47^{a}$ & $1.70 \pm 0.80^{\mathrm{b}}$ & $1.05 \pm 0.08^{b}$ \\
\hline \multicolumn{2}{|c|}{ Monoterpene ketones } & - & - & $0.68 \pm 0.08$ & - \\
\hline \multicolumn{2}{|c|}{ Phenols } & $0.84 \pm 0.10$ & $0.48 \pm 0.16^{\mathrm{a}}$ & $0.39 \pm 0.17^{\mathrm{a}}$ & - \\
\hline \multicolumn{2}{|c|}{ Monoterpene esters } & $17.42 \pm 1.66$ & $9.47 \pm 0.56^{\mathrm{a}}$ & $18.53 \pm 0.99^{b}$ & $7.39 \pm 0.75^{\mathrm{a}, \mathrm{c}}$ \\
\hline \multicolumn{2}{|c|}{ Sesquiterpenes } & $0.43 \pm 0.10$ & $1.20 \pm 0.12^{\mathrm{a}}$ & $0.43 \pm 0.04^{b}$ & - \\
\hline \multicolumn{2}{|c|}{ Fatty acid } & - & - & $0.88 \pm 0.60$ & - \\
\hline \multicolumn{2}{|l|}{ Total } & 99.99 & 99.99 & 99.99 & 100.00 \\
\hline
\end{tabular}

Data expressed as mean \pm SD of three replicates: Superscripts with different letters (a-c) within the same row represent significance level as $p^{a}<0.05$ v/s CON; $p^{b}<0.05 \mathrm{v} / \mathrm{s}$ AZOTO; $p^{c}<0.05 \mathrm{v} / \mathrm{s}$ PSB; CON-Normal control; AZOTO-Azotobacter; PSB-Phosphate solubilizing bacteria; SV-S. vermifera, Note: $(-)$ : not detected.

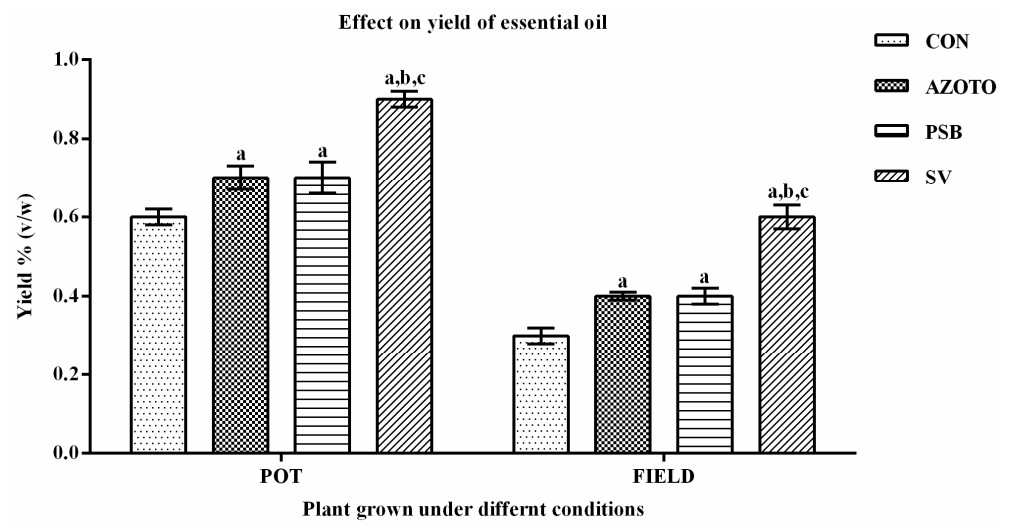

Fig. 6: Effect of treatments on the yield of EO of plant seeds under pot and field conditions: data expressed as mean \pm SD of six replicates. Superscripts with different letters (a-c) within the same condition group represent significance level as $p^{a}<0.05 \mathrm{v} / \mathrm{s}$ CON; $p^{b}<0.05 \mathrm{v} / \mathrm{s}$ AZOTO; $p^{c}<0.05$ v/s PSB; CON-Normal control; AZOTO-Azotobacter; PSB-Phosphate solubilizing bacteria; SV-S. vermifera 
Table 6: Effect of different treatments on the composition of various EO components of coriander seeds grown under field conditions

\begin{tabular}{|c|c|c|c|c|c|}
\hline \multirow[t]{2}{*}{ RT } & \multirow[t]{2}{*}{ Individual components } & \multicolumn{4}{|l|}{ Field } \\
\hline & & CON & AZOTO & PSB & SV \\
\hline 6.75 & $\alpha$-Pinene & $14.51 \pm 0.83$ & $12.25 \pm 0.88$ & $11.77 \pm 0.83^{\mathrm{a}}$ & $24.76 \pm 1.05^{\mathrm{a}, \mathrm{b}, \mathrm{c}}$ \\
\hline 7.6 & $\beta$-pienene & $2.46 \pm 0.41$ & $1.80 \pm 0.29$ & $0.40 \pm 0.17^{\mathrm{a}, \mathrm{b}}$ & $4.10 \pm 0.16^{\mathrm{a}, \mathrm{b}, \mathrm{c}}$ \\
\hline 7.81 & $\alpha$-Myrcene & $1.18 \pm 0.20$ & $0.83 \pm 0.13$ & $0.98 \pm 0.20$ & $1.48 \pm 0.16^{\mathrm{b}, \mathrm{c}}$ \\
\hline 8.5 & o-Cymene & $0.81 \pm 0.13$ & $0.90 \pm 0.11$ & $1.08 \pm 0.09$ & $1.19 \pm 0.11^{\mathrm{a}, \mathrm{b}}$ \\
\hline 8.7 & D $\neg$ Limonene & $0.92 \pm 0.16$ & $2.22 \pm 0.12^{\mathrm{a}}$ & $0.89 \pm 0.10^{\mathrm{b}}$ & $1.05 \pm 0.07^{b}$ \\
\hline 9.31 & $\Upsilon$-Terpinene & $1.66 \pm 0.24$ & $1.89 \pm 0.05$ & $0.72 \pm 0.09 \mathrm{a}, \mathrm{b}$ & $2.07 \pm 0.49 c$ \\
\hline 9.52 & trans-Linalool oxide (furanoid) & - & - & $1.17 \pm 0.19$ & - \\
\hline 9.67 & 1-Octanol & $1.32 \pm 0.13$ & $0.59 \pm 0.07$ & - & - \\
\hline 10.23 & Linalool & $48.61 \pm 1.14$ & $49.26 \pm 1.21$ & $50.34 \pm 0.92$ & $54.84 \pm 0.70^{\mathrm{a}, \mathrm{b}, \mathrm{c}}$ \\
\hline 11.14 & Citronellal & $1.15 \pm 0.19$ & $1.20 \pm 0.14$ & - & $0.95 \pm 0.08$ \\
\hline 11.15 & Nerol & - & & $1.24 \pm 0.15$ & - \\
\hline 11.61 & Borneol & $0.68 \pm 0.18$ & $0.76 \pm 0.12$ & $0.94 \pm 0.02$ & - \\
\hline 12.06 & $\alpha$-Terpineol & - & $0.85 \pm 0.13$ & $1.52 \pm 0.15$ & - \\
\hline 12.07 & Methyl chavicol & $1.07 \pm 0.04$ & - & - & - \\
\hline 12.2 & D-verbenone & - & - & $0.91 \pm 0.04$ & - \\
\hline 12.22 & Decanal & $0.72 \pm 0.07$ & $0.76 \pm 0.15$ & - & $0.77 \pm 0.04$ \\
\hline 12.78 & Citronellol & $1.58 \pm 0.12$ & - & $1.59 \pm 0.20$ & $1.33 \pm 0.20$ \\
\hline 12.75 & 1-Cyclohexene-1-carboxaldehyde,2,66-trimethyl- & - & $3.02 \pm 0.17$ & - & - \\
\hline 13.28 & Geraniol & $1.90 \pm 0.09$ & $1.51 \pm 0.09$ & $2.78 \pm 0.13^{\mathrm{a}, \mathrm{b}}$ & $1.50 \pm 0.04^{\mathrm{a}, \mathrm{c}}$ \\
\hline 13.83 & Anethole & $2.39 \pm 0.84$ & $1.20 \pm 0.15$ & $0.69 \pm 0.19^{a}$ & - \\
\hline 14.12 & Thymol & $1.03 \pm 0.08$ & $0.71 \pm 0.20$ & $0.62 \pm 0.19$ & - \\
\hline 14.27 & Undecanal & $0.70 \pm 0.14$ & $0.71 \pm 0.18$ & $0.81 \pm 0.29$ & - \\
\hline 15.18 & Citronellyl acetate & $1.22 \pm 0.16$ & $0.89 \pm 0.17$ & $1.65 \pm 0.39 \mathrm{~b}$ & $0.87 \pm 0.12^{c}$ \\
\hline 15.78 & Geranyl acetate & $14.91 \pm 1.52$ & $7.05 \pm 0.99 a$ & $16.34 \pm 0.54^{b}$ & $5.09 \pm 0.67^{\mathrm{a}, \mathrm{c}}$ \\
\hline 16.22 & Dodecanal & - & - & $0.59 \pm 0.09$ & - \\
\hline 16.85 & Caryophyllene & $0.62 \pm 0.06$ & - & $0.66 \pm 0.02$ & - \\
\hline 17.23 & 2-Dodecenal & $0.54 \pm 0.05$ & - & $0.61 \pm 0.15$ & - \\
\hline 17.84 & $\alpha$-guaiene & - & $1.51 \pm 0.08$ & - & - \\
\hline 18.05 & Longifolene & - & $6.03 \pm 0.75$ & - & - \\
\hline 18.18 & $\alpha$-Humulene & - & $1.43 \pm 0.16$ & - & - \\
\hline 18.71 & Epiglobulol & - & $1.74 \pm 0.20$ & - & - \\
\hline 20.68 & Humalane-1,6-dien-3-ol & - & $0.90 \pm 0.14$ & - & - \\
\hline 20.72 & Tetradecanal & - & - & $0.61 \pm 0.26$ & - \\
\hline 22.34 & Tetradecanoic acid & - & - & $1.11 \pm 0.56$ & - \\
\hline Monot & ene hydrocarbons & $21.54 \pm 1.97$ & $27.44 \pm 2.39^{a}$ & $15.83 \pm 1.47 \mathrm{a}, \mathrm{b}$ & $34.65 \pm 2.03^{\mathrm{a}, \mathrm{b}, \mathrm{c}}$ \\
\hline Monot & ene alcohols & $57.57 \pm 2.54$ & $56.81 \pm 2.10$ & $59.09 \pm 1.75$ & $57.67 \pm 0.94$ \\
\hline Monot & ene ethers & - & - & $1.17 \pm 0.19$ & - \\
\hline Monot & ene aldehydes & $3.11 \pm 0.45$ & $5.68 \pm 0.63^{a}$ & $2.62 \pm 0.78^{b}$ & $1.71 \pm 0.12^{\mathrm{b}}$ \\
\hline Monot & ene ketones & - & - & $0.91 \pm 0.04$ & - \\
\hline Phenol & & $1.03 \pm 0.08$ & $0.71 \pm 0.20$ & $0.62 \pm 0.19^{a}$ & - \\
\hline Monot & ene esters & $16.13 \pm 1.68$ & $7.94 \pm 1.16^{\mathrm{a}}$ & $17.99 \pm 0.93^{b}$ & $5.96 \pm 0.79^{\mathrm{a}, \mathrm{c}}$ \\
\hline Sesqui & penes & $0.62 \pm 0.06$ & $1.43 \pm 0.16^{\mathrm{a}}$ & $0.66 \pm 0.02^{b}$ & - \\
\hline Fatty a & & - & - & $1.11 \pm 0.56$ & - \\
\hline Total & & 99.99 & 100.00 & 100.00 & 99.99 \\
\hline
\end{tabular}

Data expressed as mean \pm SD of three replicates: Superscripts with different letters (a-c) within the same row represent significance level as $p^{a}<0.05 \mathrm{v} / \mathrm{s}$ CON; $p^{b}<0.05 \mathrm{v} / \mathrm{s}$ AZOTO; $p^{c}<0.05 \mathrm{v} / \mathrm{s}$ PSB; CON-Normal control; AZOTO-Azotobacter; PSB-Phosphate solubilizing bacteria; SV-S. vermifera, Note: (-): not detected

\section{Phytochemical analysis \\ Yield of essential oils}

It was observed that EO yield was significantly affected by different treatments viz. AZOTO, PSB and SV. All the treatments enhanced the yield of EO under both the conditions (pot and field) as shown in fig. 6.

\section{Comparative effect of treatments on the chemical composition} of essential oil

Effects of different treatments on EO composition of coriander in pots under greenhouse conditions are presented in table 5. Thirtyfour different EO constituents were identified during the GC-MS analysis of EO from coriander, which represented $99.99-100 \%$ of the EO. Monoterpene alcohols were the major components (56.81$59.99 \%$ ) followed by monoterpene hydrocarbons (15.83-34.65\%), monoterpene esters (5.96-18.53\%), monoterpene aldehydes (1.05$5.68 \%)$, phenols $(0.39-1.03 \%)$, sesquiterpenes $(0.43-1.43 \%)$, monoterpene ethers $(0.94-1.17 \%)$, fatty acid $(0.88-1.11 \%)$ and monoterpene ketones $(0.68-0.91 \%)$ respective to the constitution of the EO in pot and field conditions. All treatments viz. AZOTO, PSB and SV were found to significantly alter the composition of certain components of $\mathrm{EO}$ in pot and field conditions.

In pots, SV enhanced the monoterpene hydrocarbons by $57.80 \%$ and monoterpene alcohols by $0.38 \%$, whereas a negative effect was recorded on monoterpene aldehydes (decreased by 55.32\%) and monoterpene esters (decreased by $57.58 \%$ ). There was no synthesis of monoterpene ethers, monoterpene ketones, phenols, sesquiterpene and fatty acid as they were found absents in EO of SV treated plants. PSB enhanced monoterpene esters by $6.37 \%$, monoterpene alcohols by $4.22 \%$, sesquiterpene were the same relative to the $\mathrm{CON}$, whereas, a negative effect was recorded on phenols (decreased by 53.57\%), monoterpene aldehyde (decreased by $27.66 \%$ ) monoterpene hydrocarbons (decreased by $23.13 \%$ ). Surprisingly, biosynthesis of monoterpene ethers and monoterpene ketones and fatty acid was recorded in PSB groups. AZOTO enhanced sesquiterpene by $179.07 \%$, monoterpene aldehydes by $102.55 \%$, monoterpene hydrocarbons by $26.68 \%$. Negative effect was recorded on monoterpene esters (decreased 45.64\%), phenols (decreased by $42.86 \%$ ) and monoterpene alcohols (decreased by $1.04 \%)$. There was no synthesis of monoterpene ethers, 
monoterpene ketones and fatty acid. It was observed that the ethers, ketones and fatty acid were synthesized in PSB group, which were absent in all other treated groups, and a high percentage of monoterpene aldehyde was recorded in CON group only. After multi comparison, it was observed that the net effect of SV on linalool, $\alpha$ pinene and $\beta$-pinene was significantly higher in comparison to CON, PSB and AZOTO (table 5).

Effects of different treatments on EO composition of coriander under field conditions are presented in table 6. Thirty-four different constituents were identified during the GC-MS analysis of EO form coriander, which represented $99.99-100 \%$ of the EO. SV enhanced the monoterpene hydrocarbons by $60.86 \%$, monoterpene alcohols by $0.17 \%$, whereas a negative effect was recorded on monoterpene esters (decreased by $63.05 \%$ ) and monoterpene aldehyde by $45.02 \%$. There was no synthesis of monoterpene ethers, monoterpene ketones, phenols and sesquiterpene and fatty acid, as they were found absents in EO of SV treated plants. PSB enhanced monoterpene esters by $11.53 \%$ and monoterpene alcohols by $2.64 \%$ and sesquiterpene by $6.45 \%$, whereas a negative effect was recorded on phenols (decreased by 39.81\%), monoterpene hydrocarbons (decreased by $26.51 \%$ ), monoterpene aldehydes (decreased by $15.76 \%$ ) and there was bio-synthesis of monoterpene ethers and monoterpene ketones and fatty acid were recorded which was absent in all other groups. AZOTO enhanced sesquiterpenes by $130.65 \%$, monoterpene aldehydes by $82.64 \%$, monoterpene hydrocarbons by $27.39 \%$. Negative effect was recorded on monoterpene esters (decreased by $50.77 \%$ ), phenol (decreased by $31.07 \%$ ) and monoterpene alcohols (decreased by $1.32 \%)$. There was no synthesis of monoterpene ethers, monoterpene ketones and fatty acid in this group. It was observed that the ethers, ketones and fatty acid were synthesized in PSB group, which were absent in all other treated groups, and a high percentage of monoterpene aldehyde was recorded in CON group only. After multi comparison, it was observed that the net effect of SV on linalool, $\alpha$-pinene and $\beta$-pinene was significantly higher in comparison to CON, PSB and AZOTO (table 6).

\section{DISCUSSION}

This study establishes a new symbiotic relation between $S$. vermifera and $C$. sativum. our observations are in line with previous studies demonstrated the successful establishment of an association between $S$. vermifera and wide range of non-host plant species like Foeniculum vulgare [36], Nicotiana attenuata [37], Thymus vulgaris [38], Panicum virgatum [39,40] and Oryza sativa [41].

In this study, we observed that the application of fungi (SV) and plant beneficial bacteria (AZOTO and PSB) altered the emergence traits of coriander seeds. The seed emergence depends largely on reserve energy store and driven by a complex sequence of imbibitions, enzymatic phytohormonal influence and not on the external nutrients. However, the acceleration in emergence traits could be ascribed to the phytohormones and other complex mixture of growth-promoting metabolites that are modulated by plant biologicals such as A. chroococcum [42], P. fluorescens [43, 44] and mycorrhizal fungus [45]. Similarly, A. chroococcum [46] and $P$. fluorescens [47] have variously been reported with the potential to accelerate the germination and vigour of seedlings [48, 49]. $S$. vermifera has also been reported to enhance the germination of $P$. virgatum plant in petri plates and to stimulate seed germination, increase growth and stalk elongation along with earlier flowering, more flower yield and greater maturation of seed capsules in Nicotiana attenuata [37, 45].

In the present study the application of S. vermifera, A. chroococcum and $P$. fluorescens showed an acceleration in emergence traits of seeds but especially $S$. vermifera showed a pronounced acceleration which was significant in comparison to non-colonized and $A$. chroococcum treated plants, even some traits were significantly different when compared with $P$. fluorescens treated plants. Although, the underlying mechanisms responsible for the accelerated emergence traits by $S$. vermifera are unknown, it is assumed that phytohormonal synthesis and signaling by $S$. vermifera were strong enough to accelerate the emergence traits of the seeds greater than other treatments. Piriformospora indica, a closely related fungus of same order (Sebacinales), had already been documented to modulate the regulation and signaling of auxins and cytokinins [50, 51]. Similarly, enhanced seed germination observed in the presence of the $S$. vermifera could be related to inhibition of ethylene signaling [52].

During this study, we found that the overall emergence properties were better in pot trials as compared to field trials. Seed germination is an extremely sophisticated process driven by several exogenous conditions include right temperature, water, oxygen or air and sometimes light or darkness [53]. Under favorable conditions seeds germinate and develop towards seedlings whereas unfavorable conditions turn seeds to dormant or damage embryo. We speculate that under field the unfavorable conditions prevented the metabolic processes and growth of embryonic tissues resulted in lesser emergence whereas, better emergence response under pot condition might be attributed to environmentally controlled, favourable conditions. It is noteworthy that although absolute numbers in two conditions (pot and field) were not exactly matching, however, the relative effects by all the three biologicals were similar under both the controlled (pot) and uncontrolled (field) conditions.

Another set of results during this study indicated that the treatment of coriander plantlets with three different biologicals (SV, AZOTO and PSB) resulted in excellent growth of $C$. sativum resulting in overall enhanced total length, total fresh weight and total dry weight of treated plants when it was compared with non-treated plants. Similar effects by these organisms have earlier been reported for plant varieties other than coriander. The beneficial effects of $A$. chroococcum have been reported previously with respect to its effect on increasing plant biomass and plant height of Triticum aestivum and Adathoda vasica [54, 55]. Similarly, P. fluorescens was found to increase the leaves number, branches number, height and number of nodule/plant in V. faba [56] whereas, it improved the total weight, root weight and shoot weight of Pisum sativum L. [57]. S. vermifera has also been reported to increases plant height, root length and biomass production in treated plants $[36,38,41,45,58]$.

Profuse root systems support the greater potential of the plant to hold soil, larger exposure, as well as sequester of water and nutritive entities $[39,50]$ and literature reports, suggests that the plant biologicals help with better root development in plants. In earlier studies, it has been reported that $A$. chroococcum [59] P. fluorescens [56]. S. vermifera $[41,45]$ enhances the root length and volume. It was hypothesized that the significant growth in root system of plants treated with biological agents could be due to phytohormonal involvements [51]. Several investigations are in agreement with this hypothesis demonstrated that A. chroococcum [59], Pseudomonas species [60] produced a significant level of phytohormones, which resulted in root elongation of tested plants. Further, it has also been suggested that about $80 \%$ of the soil bacteria can produce phytohormone (Indole acetic acid) [61]. In context to $S$. vermifera, closely related fungus $P$. indica, had also been proved to produce phytohormones in inoculated plants [50,58,62,63]. Similarly, we also observed that all three different treatments (SV, AZOTO and PSB) resulted in a highly developed root system with extensive secondary roots and lateral branches (data not shown here), which could be attributed to the possible phytohormones production in treated coriander plants. The enhanced root system of treated plants mined the niche to a great extent in terms of essential nutrients, which was supported by the accumulation of different nutrients in the plants (data not shown).

Besides, these Azotobacter is non-symbiotic heterotrophic bacteria and largely associated with $\mathrm{N}$ fixation in the niche of the plant [64, 65]. Increased $\mathrm{N}$ availability by $A$. chroococcum has been demonstrated by Lévai et al. (2008) [66] and Chaudhary et al. (2013) [55]. Similarly, Pseudomonas genus is known as the most powerful P solubilizer [67]. P. fluorescens has been demonstrated for $\mathrm{P}$ solubilization in vitro [68-70] as well as in the niche of the plant where enhanced biomass was also observed in associated plants [57]. On the other hand, S. vermifera is a symbiotic mycorrhiza and mycorrhizal symbiosis is well known to facilitate a wide range of macro-and micronutrients. Several investigations demonstrated that $S$. vermifera colonized plants showed a significant increase in N, 
$\mathrm{P}$ and $\mathrm{K}$ contents $[40,41,45]$. P. indica a closely related fungus has also been demonstrated to facilitate the $\mathrm{N}, \mathrm{P}$ and $\mathrm{K}[71,72]$, in addition to this expression of nitrate reductase (Nia2) and phosphate transporter (PiPT) (which actively involved in the assimilation of nitrogen and in phosphate transportation, respectively) has been reported in closely related mycorrhiza- $P$. indica colonized plants [73-75].

In our study, $S$. vermifera was observed with prominent effects on length and biomass among all treatments. Because macronutrients, especially $\mathrm{N}$ and $\mathrm{P}$ are essential elements for plant growth and they could affect plant biomass accumulation, biomass allocation, growth and seed quantity and quality [76]. So it is tempting to speculate that enhancement in length and biomass by $S$. vermifera is based on availability and efflux of multi integrated nutrients by extensive roots and fungal hyphae. It is well known that the fungal hyphae, along with the roots, explore a larger volume of soil and exploit nutrients from a greater surface area [77], whereas the enhancement by PSB is restricted to P availability and enhancement by Azotobacter is restricted to $\mathrm{N}$ availability only. Our speculation is supported by $P$. indica, which has been proved to increase the uptake of macronutrients (N, P, K) [72] and micronutrients (Cu, Fe, $\mathrm{Zn}, \mathrm{Mn}$ ) in colonized plants [78]. Further enhanced biomass accumulation by biologicals treated plants was supported by elemental analysis of $\mathrm{C}$, Hydrogen $(\mathrm{H})$ and $\mathrm{N}$ from plant's dry matter (Data is not shown here). $\mathrm{C}, \mathrm{H}$ and $\mathrm{N}$ are major contributors to the plant biomass. So higher enhancement in biomass of plant and results of elemental analysis both are in agreement with the fact that S. vermifera facilitates nutrient availability and hence enhances the growth and biomass of treated plants to a great extent.

Notably, seeds yield and level of seed EO were found to be significantly enhanced with the better composition of EO in treated plants of the present study. Earlier, it was reported that $A$. chroococcum not merely fixes the nitrogen but also could stimulate the growth of the plant, the yield of seeds and subsequently can improve the yield of EO and their components in $F$. vulgare [79]. Similarly, it was reported that $A$. chroococcum in combination with other microorganisms, increased the yield of EO in C. sativum [80, 81]. P. fluorescens treatment has also been reported to increase the yield of EO in Origanum majorana [82] and Ocimum basilicum [83]. Microbial volatile organic compounds emitted by associated bacterial strains during plant-microbe interaction has been reported to enhance the production of biomass and EO in micro propagated M. piperita [84]. Similar observations were reported with $S$. vermifera on fennel (F. vulgare) and thyme (T. vulgaris) $[36,38]$. Although the underlying mechanism of increasing EO yield by microorganisms is still not known, it was suggested that enhanced yield of EO might be attributed to enhanced nutrient availability [85], and increased biosynthesis of terpenes production [82]. The increased EO yield may be associated with defensive response [82] and may depends upon many factors, including alteration in plant morphology, gene expression involved in the monoterpene biosynthetic pathway $[86,87]$ and $\mathrm{P}$ availability in plant [88-92]. These factors, either alone or in combination, have the potential to enhance the monoterpene accumulation in colonize plants. Further, EO represents an important diverse group of terpenoids which are synthesized from universal precursors, isopentenyl pyrophosphate (IPP) and its isomer dimethylallyl pyrophosphate (DMAPP) units in the isoprenoid pathway [93]. These precursors require acetyl-CoA, adenosine triphosphate (ATP) and nicotinamide adenine dinucleotide phosphate (NADPH) for synthesis and are dependent on P availability in the plant [94]. It is likely that during the present study, S. vermifera stimulated the P mediated IPP and DMAPP synthesis better than other microorganisms, resulted in an observed higher yield of EO from seeds of $C$. sativum.

It is also noteworthy that application of different microorganisms consistently altered the composition of secondary metabolites present in EO i.e. linalool (monoterpene alcohol), $\alpha$-, $\beta$-pinene and (monoterpene hydrocarbon) and geranyl acetate (monoterpene acetate) consistently which were significantly different on comparison to control plants under both pots (greenhouse) and field conditions in the present study. This report is in the alignment of earlier reports where $A$. chroococcum in consortia had consistently enhanced the secondary metabolites stevioside in Stevia rebaudiana $[95,96]$ and anethole level in F. vulgare [79]. P. fluorescens has also been reported to enhance the tropane alkaloids hyoscyamine and scopolamine in black henbane-Hyoscyamus niger [97] and also (+) pulegone (-) menthone level in M. piperita [84]. Similarly, $S$. vermifera has been reported to enhance the level of podophyllotoxin and its 6-methoxy derivative in Linum album [98-100], anethole level in F. vulgar [36] and thymol level in T. vulgaris [38]. The synthesis of secondary metabolites does not merely depend upon internal factors like genetics and various growth stages but also on external factors like environmental conditions and biotic and abiotic stresses, which could influence the biochemical pathways along with phytometabolic processes and hence the synthesis of EO [101-103]. Additionally, precursor and elicitor of fungal origins are also proving an effective approach to enhance secondary metabolites in plant cell culture [104-106]. Enhancement in commercially important secondary metabolites i.e. artemisinin and withaferin-A were already achieved in cell culture technique facilitated with elicitor of fungal origins $[107,108]$.

Although the enhancements in various components by PSB were also high followed by AZOTO but the enhancement in major components of EO were significantly high in SV treated group in comparison to other three groups i.e. CON, PSB, AZOTO. While the underlying mechanism(s) behind the unique ability of $S$. vermifera to alter the plant metabolomics profile and alter the synthesis of a particular component in aromatic plants has not yet been elucidated, but it is tempting to speculate that the availability of integrated multi nutrients and S. vermifera mediated regulation of synthesis and signaling of phytohormones and stimulus to the defense pathway [99] are responsible for the defensive response and fitness of plant and hence, enhance the different class of monoterpenes in the EO. Baldi et al. (2010) [21] suggested that the elicitors of fungal origin have potential to activate biosynthetic pathway and hence enhance secondary metabolites production in cell cultures. In previous study, it was shown that the $S$. vermifera enhances the Phenylalanine Ammonialyase (PAL) activity, where PAL is known to play key role in phenylpropanoid pathway to synthesize lignan [100].

To the best of our knowledge, this is the first report on the mutualistic symbiosis of $C$. sativum and S. vermifera, which has great potential for sustainable agricultural practices in context to coriander. S. vermifera was capable of establishing mutualistic relationships in $C$. sativum roots and exert multifaceted benefits which include accelerated germination of seeds; stimulated nutrient absorption; promotion of vegetation; enhanced biomass of the plants; increased yield of EO and its composition.

\section{CONCLUSION}

Based on the results of present study, it is concluded that $S$. vermifera possesses immense potentials in the pursuit of agronomical attributes of medicinal plant cultivation and crop production as well. It showed excellent effects on emergence, phytopromotion and phytochemical production. Application of $S$. vermifera consistently accelerated the phytochemical traits of plant no matter in pots of greenhouse or field conditions. Colonized coriander plant showed a better architect in healthy root system and pronounced vegetation in shoot system followed by seed and EO production. Based on the findings of this study, it is recommended that $S$. vermifera have the potential to serve as ecofriendly inputs for organic farming and can help with curtailing the requirements of costly fertilizers, which are deleterious to environment as well as human health. It can be efficiently used for sustainable ecofriendly and safe agronomical practices also medicinal plant production having the economic and commercial values in general, and specifically $C$. sativum. Additionally, $S$. vermifera/C. sativum symbiosis opens an exciting area of scientific exploration, pertaining to the molecular investigation of seed germination, phytopromotion and enhancement in secondary metabolites.

\section{ACKNOWLEDGEMENT}

Authors are thankful to Science and Engineering Board (SERB), Department of Science and Technology, Govt. of India, New Delhi for providing financial assistance under Fast Track Scheme (DST-SERB- 
FTYS) to Dr. Ashish Baldi. Authors are also thankful to Mr. Pankaj Samuel and Mr. Neeraj Jaswal (CIL, Panjab University, Chandigarh, India) for their help in GC analysis and organic elemental analysis.

\section{FUNDING}

This study was fully funded by the Science and Engineering Board (SERB), Department of Science and Technology, Govt. of India, New Delhi, under Fast Track Scheme (DST-SERB FTYS) to Dr. Ashish Baldi.

\section{AUTHORS CONTRIBUTIONS}

The corresponding author, Dr. Ashish Baldi designed the work and supervised the experimentation. Mr. Kamal Jeet performed the experiment, collected data, analyzed and prepared, the manuscript. Dr. Alok Malaviya reviewed and edited the manuscript.

\section{CONFLICT OF INTERESTS}

The authors declare that they have no conflict of interest

\section{REFERENCES}

1. Small E. Culinary herbs. Ottawa: NRC Research Press; 1997.

2. Dyulgerov N, Dyulgerova B. Heritability and correlation coefficient analysis for fruit yield and its components in coriander (Coriandrum sativum L.). Turk J Agric Nat Sci 2014;1:618-22.

3. Nadeem M, Anjum FM, Khan MI, Tehseen S, El-Ghorab A, Sultan JI. Nutritional and medicinal aspects of Coriander (Coriandrum sativum L.) a review. $\mathrm{Br}$ Food J 2013;115:743-55.

4. Zheljazkov VD, Pickett KM, Caldwell CD, Pincock JA, Roberts JC, Mapplebeck L. Cultivar and sowing date effects on seed yield and oil composition of Coriander in Atlantic Canada. Ind Crops Prod 2008;28:88-94.

5. Diederichsen A. Coriander: Coriandrum Sativum L. Rome: Gatersleben/IPGRI; 1996.

6. Gray AM, Flatt PR. Insulin-releasing and insulin-like activity of the traditional anti-diabetic plant Coriandrum sativum (coriander). Br J Nutr 1999;81:203-9.

7. Carrubba A, la Torre R, Di Prima A, Saiano F, Alonzo G. Statistical analyses on the essential oil of Italian Coriander (Coriandrum sativum L.) fruits of different ages and origins. J Essential Oil Res 2002;14:389-96.

8. Wangensteen H, Samuelsen AB, Malterud KE. Antioxidant activity in extracts from coriander. Food Chem 2004;88:293-7.

9. Emamghoreishi M, Khasaki M, Aazam MF. Coriandrum sativum: evaluation of its anxiolytic effect in the elevated plus-maze. J Ethnopharmacol 2005;96:365-70.

10. Darughe F, Barzegar M, Sahari MA. Antioxidant and antifungal activity of Coriander (Coriandrum sativum L.) essential oil in cake. Int Food Res J 2012;19:1253-60.

11. Eidi M, Eidi A, Saeidi A, Molanaei S, Sadeghipour A, Bahar M, et al. Effect of coriander seed (Coriandrum sativum $L$ ) ethanol extract on insulin release from pancreatic beta cells in streptozotocin-induced diabetic rats. Phytother Res 2008;23:404-6.

12. Cortes Eslava J, Gomez Arroyo S, Villalobos Pietrini R, Espinosa Aguirrec JJ. Antimutagenicity of coriander (Coriandrum sativum) juice on the mutagenesis produced by plant metabolites of aromatic amines. Toxicol Lett 2004;153:283-92.

13. Sunil C, Agastian P, Kumarappan C, Ignacimuthu S. In vitro antioxidant, antidiabetic and antilipidemic activities of Symplocos cochinchinensis (Lour.) S. Moore bark. Food Chem Toxicol 2012;50:1547-53.

14. UNDESA. World population projected to reach 9.8 billion in 2050, and 11.2 billion in 2100. United Nations Department of Economic and Social Affairs. Available from: https://www.un.org/development/desa/en/news/population /world-population-prospects-2017.html. [Last accessed on 10 Sep 2017].

15. Smith SE, Read DJ. Mycorrhizal symbiosis. New York: Academic Press; 1995.
16. Ahmad F, Ahmad I, Khan MS. Screening of free-living rhizospheric bacteria for their multiple plant growth promoting activities. Microbiol Res 2008;63:173-81.

17. Gupta M, Kiran S, Gulati A, Singh B, Tewari R. Isolation and identification of phosphate solubilizing bacteria able to enhance the growth and aloin-a biosynthesis of Aloe barbadensis miller. Microbiol Res 2012;167:358-63.

18. Novozymes. The BioAg alliance advances new microbial solutions for agriculture: Strong pipeline of microbial products designed to boost crop yields in a sustainable way. Novozymes. Available from: https://www.novozymes.com/news/newsarchive/2017/01/bioag-alliance-pipeline-2017. [Last accessed on 10 Sep 2017]

19. Mehrotra VS. Mycorrhiza: role and applications. New Delhi: Allied Publishers; 2005.

20. Allen MF. The ecology of mycorrhizae. USA: Cambridge University Press; 1991.

21. Baldi A, Farkya S, Jain A, Gupta N, Mehra R, Datta V, et al. Enhanced production of podophyllotoxins by co-culture of transformed Linum album cells with plant growth-promoting fungi. Pure Appl Chem 2010;82:227-41.

22. Saharan BS, Nehra V. Plant growth promoting rhizobacteria: a critical review. Life Sci Med Res 2011;2:1-30.

23. Bona E, Cantamessa S, Massa N, Manassero P, Marsano F, Copetta A, et al. Arbuscular mycorrhizal fungi and plant growth-promoting Pseudomonads improve yield, quality and nutritional value of tomato: a field study. Mycorrhiza 2017;27:1-11.

24. ISTA. International rules for seed testing. Seed Sci Technol 1985;13:299-513.

25. Association of Official Seed Analysis (AOSA). Seed vigor testing handbook. Contribution no. 32 to the handbook on Seed Testing; 1983.

26. Ellis RH, Roberts EH. The quantification of ageing and survival in orthodox seeds. Seed Sci Technol 1981;9:373-409.

27. Dezfuli PM, Sharif Zadeh F, Janmohammadi M. Influence of priming techniques on seed germination behavior of maize inbred lines (Zea mays L.). Arpn J Agric Biol Sci 2008;3:22-5.

28. Coolbear P, Francis A, Grierson D. The effect of low temperature pre-sowing treatment under the germination performance and membrane integrity of artificially aged tomato seeds. J Exp Bot 1984;35:1609-17.

29. Farooq M, Basra SMA, Ahmad N, Hafeez K. Thermal hardening: a new seed vigor enhancement tool in rice. J Integr Plant Biol 2005;47:187-93.

30. Farooq M, Basra SMA, Hafeez-ue-Rehman, Mehmood T. Germination and early seedling growth as affected by presowing ethanol seed treatments in fine rice. Int J Agric Biol 2006;8:19-22.

31. Srinivasan K, Saxena S. Effect of dormancy breaking treatments on seed quality during storage of four acacia species. Indian J Forest 2007;30:233-40.

32. Abdul Baki AA, Anderson JD. Vigour determination in soybean seed by multiple criteria. Crop Sci 1973;13:630-3.

33. Phillip JM, Hayman DS. Improved procedures for clearing roots and staining parasitic and VAM fungi for rapid assessment of infection. T Br Mycol Soc 1970;55:158-61.

34. Giovannetti M, Mosse B. An evaluation of techniques for measuring vesicular-arbuscular mycorrhizal infection in roots. New Phytol 1980;84:489-500.

35. Tarraf W, Ruta C, Tagarelli A, De Cillis F, De Mastro G. Influence of arbuscular mycorrhizae on plant growth, essential oil production and phosphorus uptake of Salvia officinalis L. Ind Crops Prod 2017; 102:144-53.

36. Dolatabadi HK, Goltapeh EM, Jaimand K, Rohani N, Varma A. Effects of Piriformospora indica and Sebacina vermifera on growth and yield of essential oil in Fennel (Foeniculum vulgare) under greenhouse conditions. J Basic Microbiols 2011;51:33-9.

37. Barazani O, Benderoth M, Groten K, Kuhlemeier C, Baldwin IT. Piriformospora indica and Sebacina vermifera increase growth performance at the expense of herbivore resistance in Nicotiana attenuata. Oecologia 2005;146:234-43.

38. Dolatabadi HK, Goltapeh EM, Moieni A, Jaimand K, Sardrood BP, Varma A. Effect of Piriformospora indica and Sebacina vermifera 
on plant growth and essential oil yield in Thymus vulgarisin vitro and in vivo experiments. Symbiosis 2011;53:29-35.

39. Ghimire SR, Craven KD. Enhancement of switchgrass (Panicum virgatum L.) biomass production under drought conditions by the ectomycorrhizal fungus Sebacina vermifera. Appl Environ Microbiol 2011;77:7063-7.

40. Ray P, Ishiga T, Decker SR, Turner GB, Craven KD. A novel delivery system for the root symbiotic fungus, Sebacina vermifera, and consequent biomass enhancement of low lignin COMT switchgrass lines. BioEnergy Res 2015;8:922-33.

41. Pirdashti H, Yaghoubian Y, Goltapeh E, Hosseini S. Effect of mycorrhiza-like endophyte (Sebacina vermifera) on growth, yield and nutrition of rice (Oryza sativa L.) under salt stress. J Agric Technol 2012;8:1651-61.

42. Harper SHT, Lynch JM. Effects of Azotobacter chroococcum on barley seed germination and seedling development. Microbiology 1979;112:45-51.

43. Gholami A, Shahsavani S, Nezarat S. The effect of plant growth promoting rhizobacteria (PGPR) on germination, seedling growth and yield of Maize. Int J Biol Bioml Agric Food Biotechnol Eng 2009;3:9-14.

44. Ardebili ZO, Ardebili NO, Hamdi SMM. Physiological effects of Pseudomonas fluorescens CHA0 on tomato (Lycopersicon esculentum Mill.) plants and its possible impact on Fusarium oxysporum f. sp. lycopersici. Aust J Crop Sci 2011;5:1631-8.

45. Ghimire SR, Charlton ND, Craven KD. The mycorrhizal fungus, Sebacina vermifera, enhances seed germination and biomass production in switchgrass (Panicum virgatum L) Bioenergy Res 2009;2:51-8.

46. Yousefi S, Kartoolinejad D, Bahmani M, Naghdi R. Effect of Azospirillum lipoferum and Azotobacter chroococcum on germination and early growth of hopbush shrub (Dodonaea viscosa L.) under salinity stress. J Sustainable Forest 2017;36:107-20.

47. Demissie S, Muleta D, Berecha G. Effect of phosphate solubilizing bacteria on seed germination and seedling growth of Faba Bean (Vicia faba L.). Int J Agric Res 2013;8:123-36.

48. Nandakumar R, Babua S, Viswanathan R, Raguchandera T, Samiyappan R. Induction of systemic resistance in rice against sheath blight disease by Pseudomonas fluorescens. Soil Biol Biochem 2001;33:603-12.

49. Abo Elyousr KAM, El-Hendawy HH. Integration of Pseudomonas fluorescens and acibenzolar-S-methyl to control bacterial spot disease of tomato. Crop Prot 2008;27:1118-24.

50. Sirrenberg A, Gobel C, Grond S, Czempinski N, Ratzinger A, Karlovsky P, et al. Piriformospora indica affects plant growth by auxin production. Physiol Plant 2007;131:581-9.

51. Vadassery J, Ritter C, Venus Y, Camehl I, Varma A, Shahollari B, et al. The role of auxins and cytokinins in the mutualistic interaction between Arabidopsis and Piriformospora indica. Mol Plant Microbe Interact 2008;21:1371-83.

52. Barazani 0, Von Dahl CC, Baldwin IT. Sebacina vermifera promotes the growth and fitness of Nicotiana attenuata by inhibiting ethylene signaling. Plant Physiol 2007;144:1223-32.

53. Raven PH, Evert RF, Eichhorn SE. Biology of plants. New York: WH Freeman and Company Publishers; 2005.

54. Ananthanaik T, Earanna N, Suresh CK. Influence of Azotobacter chroococcum strains on growth and biomass of Adathoda vasica Nees. Karnataka J Agric Sci 2007;20:613-5.

55. Chaudhary D, Narula N, Sindhu SS, Behl RK. Plant growth stimulation of wheat (Triticum aestivum L.) by inoculation of salinity tolerant Azotobacter strains. Physiol Mol Biol Plants 2013;19:515-9.

56. Alemu F, Alemu T. Pseudomonas fluorescens isolates used as a plant growth promoter of Faba Bean (Vicia faba) in vitro as well as in vivo study in Ethiopia. Am J Life Sci 2015;3:100-8.

57. Otieno N, Lally RD, Kiwanuka S, Lloyd A, Ryan D, Germaine KJ, et al. Plant growth promotion induced by phosphate solubilizing endophytic Pseudomonas isolates. Front Microbiol 2015;6:745.

58. Dolatabadi HK, Goltapeh EM, Moieni A, Varma A. Evaluation of different densities of auxin and endophytic fungi (Piriformospora indica and Sebacina vermifera) on Mentha piperita and Thymus vulgaris growth. Afr J Biotechnol 2012;11:1644-50.
59. Karthikeyan A, Sakthivel KM. Efficacy of Azotobacter chroococcum in rooting and growth of Eucalyptus camaldulensis stem cuttings. Res J Microbiol 2011;6:618-24.

60. Xie H, Pastrnak JJ, Gilck BR. Isolation and characterization of mutants of plant growth promoting rhizobacteria Pseudomonas putida, GR12-2 that over produced indole acetic acid. Curr Microbiol 1966;32:67-71.

61. Glick BR, Patten CL, Holguin G, Penrose DM. Biochemical and genetic mechanisms used by plant growth promoting bacteria. London: Imperial College Press; 1999.

62. Lee YC, Johnson JM, Chien CT, Sun C, Cai DG, Lou BG, et al. Growth promotion of Chinese cabbage and Arabidopsis by Piriformospora indica is not stimulated by myceliumsynthesized auxin. Mol Plant Microbe Interact 2011;24:421-31.

63. Dong SQ, Tian ZH, Chen PJ, Kumar RS, Shen CH, Cai DG. The maturation zone is an important target of Piriformospora indica in Chinese cabbage roots. J Exp Bot 2013;64:4529-40.

64. Lakshminarayana K. Influence of Azotobacter on nitrogen nutrition of plants and crop productivity. Proc Indian Natn Sci Acad B 1993;59:303-8.

65. Kizilkaya R. Nitrogen fixation capacity of Azotobacter spp. strains isolated from soils in different ecosystems and relationship between them and the microbiological properties of soils. J Environ Biol 2009;30:73-82.

66. Levai L, Veres S, Bakonyi N, Gajdos E. Can wood ash and biofertilizer play a role in organic agriculture? Agronomski Glasnik 2008;70:263-72.

67. Rodríguez H, Fraga R. Phosphate solubilizing bacteria and their role in plant growth promotion. Biotechnol Adv 1999;17:319-39.

68. Di Simine CD, Sayer JA, Gadd GM. Solubilization of zinc phosphate by a strain of Pseudomonas fluorescens isolated from a forest soil. Biol Fertil Soils 1998;28:87-94.

69. Henri F, Laurette NN, Annette D, John Q, Wolfgang M, Franccedil E, et al. Solubilization of inorganic phosphates and plant growth promotion by strains of Pseudomonas fluorescens isolated from acidic soils of Cameroon. Afr J Microbiol Res 2008;2:171-8.

70. Goteti PK, Desai S, Emmanuel LDA, Taduri M, Sultana U. Phosphate solubilization potential of Fluorescent Pseudomonas spp. isolated from diverse agro-ecosystems of India. Int J Soil Sci 2014;9:101-10.

71. Nautiyal CS, Chauhan PS, DasGupta SM, Seem K, Varma A, Staddon WJ. Tripartite interactions among Paenibacillus lentimorbus NRRL B-30488, Piriformospora indica DSM 11827, and Cicer arietinum L. World J Microbiol Biotechnol 2010;26:1393-9.

72. Kumar V, Sarma MVRK, Saharan K, Srivastava R, Kumar L, Sahai Vikram, et al. Effect of formulated root endophytic fungus Piriformospora indica and plant growth promoting rhizobacteria fluorescent pseudomonads R62 and R81 on Vigna mungo. World J Microbiol Biotechnol 2012;28:595-603.

73. Sherameti I, Shahollari B, Venus Y, Altschmied L, Varma A, Oelmüller R. The endophytic fungus Piriformospora indica stimulates the expression of nitrate reductase and the starchdegrading enzyme glucan-water dikinase in tobacco and Arabidopsis roots through a homeodomain transcription factor that binds to a conserved motif in their promoters. J Biol Chem 2005;280:26241-7.

74. Yadav V, Kumar M, Deep DK, Kumar H, Sharma R, Tripathi T, et al. A phosphate transporter from the root endophytic fungus Piriformospora indica plays a role in phosphate transport to the host plant. J Biol Chem 2010;285:26532-44.

75. Kumar M, Yadav V, Kumar H, Sharma R, Singh A, Tuteja N, et al. Piriformospora indica enhances plant growth by transferring phosphate. Plant Signal Behav 2011;6:723-5.

76. Li Y, Hou L, Song B, Yang L, Li L. Effects of increased nitrogen and phosphorus deposition on offspring performance of two dominant species in a temperate steppe ecosystem. Sci Rep 2017;7:40951.

77. Satheesan J, Narayanan AK, Sakunthala M. Induction of root colonization by Piriformospora indica leads to enhanced asiaticoside production in Centella asiatica. Mycorrhiza 2012;22:195-202.

78. Gosal SK, Karlupia A, Gosal SS, Chhibba IM, Varma A. Biotization with Piriformospora indica and Pseudomonas 
fluorescens improves survival rate, nutrient acquisition, field performance and saponin content of micropropagated Chlorophytum sp. Indian J Biotechnol 2010;9:289-97.

79. Mahfouz SA, Sharaf-Eldin MA. Effect of mineral vs. biofertilizer on growth, yield, and essential oil content of fennel (Foeniculum vulgare Mill.). Int Agrophysics 2007;21:361-6.

80. Shirkhodaei M, Darzi MT, Hadi MHS. Influence of vermicompost and biostimulant on the growth and biomass of coriander (Coriandrum sativum L.). Int J Adv Biol Biomed Res 2014;2:706-14.

81. Darzi MT, Shirkhodaei M, Hadi MRHS. Effects of vermicompost and nitrogen fixing bacteria on seed yield, yield components of seed and essential oil content of coriander (Coriandrum sativum). J Med Plants By-Prod 2015;14:103-9.

82. Banchio E, Bogino PC, Zygadlo J, Giordano W. Plant growth promoting rhizobacteria improve growth and essential oil yield in Origanum majorana L. Biochem Syst Ecol 2008;36:766-71.

83. Hemavathi, Navi V, Sivakumr BS, Suresh CK, Earanna N. Effect of Glomus fasciculatum and plant growth promoting rhizobacteria on growth and yield of Ocimum basilicum. Karnataka J Agric Sci 2006;19:17-20.

84. Santoro MV, Zygadlo J, Giordano W, Banchio E. Volatile organic compounds from rhizobacteria increase biosynthesis of essential oils and growth parameters in peppermint (Mentha piperita). Plant Physiol Biochem 2011;49:1177-82.

85. Abdelaziz ME, Pokluda R, Abdelwahab MM. Influence of compost, microorganisms and NPK fertilizer upon growth, chemical composition and essential oil production of Rosmarinus officinalis L. Not Bot Horti Agrobot Cluj Napoca 2007;35:86-90.

86. Floß DS, Hause B, Lange PR, Kuester H, Strack D, Walter MH. Knock-down of the MEP pathway isogene 1-deoxy-d-xylulose 5-phosphate synthase 2 inhibits formation of arbuscular mycorrhiza-induced apocarotenoids, and abolishes normal expression of mycorrhiza-specific plant marker genes. Plant J 2008;56:86-100.

87. Mandal S, Upadhyay S, Singh VP, Kapoor R. Enhanced production of steviol glycosides in mycorrhizal plants: a concerted effect of arbuscular mycorrhizal symbiosis on transcription of biosynthetic genes. Plant Physiol Biochem 2015;89:100-6.

88. Torelli A, Trotta A, Acerbi L, Arcidiacono G, Berta G, Branca C. IAA and ZR content in leek (Allium porrum L.), as influenced by $\mathrm{P}$ nutrition and arbuscular mycorrhizae, in relation to plant development. Plant Soil 2000;226:29-35.

89. Kapoor R, Giri B, Mukerji KG. Glomus macrocarpum: a potential bioinoculant to improve essential oil quality and concentration in dill (Anethum graveolens L.) and Carum (Trachyspermum ammi (Linn.) Sprague). World J Microbiol Biotechnol 2002;18:459-63.

90. Strack D, Fester T, Hause B, Schliemann W, Walter MH. Review paper: arbuscular mycorrhiza: biological, chemical, and molecular aspects. J Chem Ecol 2003;29:1955-79.

91. Krishna H, Singh SK, Sharma RR, Khawale RN, Grover M, Patel VB. Biochemical changes in micropropagated grape (Vitis vinifera L.) plantlets due to arbuscular-mycorrhizal fungi (AMF) inoculation during ex vitro acclimatization. Sci Hort 2005;106:554-67.

92. Sailo GL, Bagyaraj DJ. Influence of different AM-fungi on the growth, nutrition and forskolin content of Coleus forskohlii. Mycol Res 2005;109:795-8.
93. Prasad A, Kumar S, Pandey A, Chand S. Microbial and chemical sources of phosphorus supply modulate the yield and chemical composition of essential oil of rose-scented geranium (Pelargonium species) in sodic soils. Biol Fertil Soils 2012;48:117-22.

94. Loomis WD, Corteau R. Biochemistry and physiology of lower terpenoids. Recent Adv Phytochem 1973;6:147-85.

95. Vafadar F, Amooaghaie R, Otroshy M. Effects of plant-growthpromoting rhizobacteria and arbuscular mycorrhizal fungus on plant growth, stevioside, NPK, and chlorophyll content of Stevia rebaudiana. J Plant Interact 2014;9:128-36.

96. Kilam D, Saifi M, Abdin MZ, Agnihotri A, Varma A. Combined effects of Piriformospora indica and Azotobacter chroococcum enhance plant growth, antioxidant potential and steviol glycoside content in Stevia rebaudiana. Symbiosis 2015;66:149-56.

97. Ghorbanpour M, Hatami M, Khavazi K. Role of plant growth promoting rhizobacteria on antioxidant enzyme activities and tropane alkaloid production of Hyoscyamus niger under water deficit stress. Turk J Biol 2013;37:350-60.

98. Baldi A. Production of anticancer drug, podophyllotoxin, by plant cell cultivation of Linum album. India, New Delhi: Dissertation, Indian Institute of Technology Delhi; 2008.

99. Baldi A, Jain A, Gupta N, Srivastava AK, Bisaria VS. Co-culture of arbuscular mycorrhiza-like fungi (Piriformospora indica and Sebacina vermifera) with plant cells of Linum album for enhanced production of podophyllotoxins: a first report. Biotechnol Lett 2008;30:1671-7.

100. Farkya S, Baldi A, Kumar V, Datta V, Mehra R, Gupta N, et al. Impact of symbiotic fungi on production of secondary metabolites by plant cell culture. AsPac J Mol Biol Biotechnol 2010;18:51-3.

101. Sangwan NS, Farooqi AHA, Shabih F, Sangwan RS. Regulation of essential oil production in plants. Plant Growth Regul 2001;34:3-21.

102. Lima HRP, Kaplan MAC, Cruz AVM. Influence of abiotic factors on terpenoids production and variability in the plants. Florestae Ambiente 2003;10:71-7.

103. Gobbo Neto L, Lopes NP. Medicinal plants: factors of influence on the content of secondary metabolites. Quim Nova 2007;30:374-81.

104. Bisaria VS, Baldi A, Kumar V, Gupta N, Jain A, Farkya S, et al. Interaction of phytopromotional fungi and plant cells on synthesis of plant-derived metabolites. J Biotechnol 2008;136:S11.

105. Baldi A, Jain A, Gupta N, Srivastava AK, Bisaria VS. Co-culture of Linum album cells and Piriformospora indica for improved production of phytopharmaceuticals. In: Varma A, Kharkwal AC. (ed) Symbiotic fungi. Berlin Heidelberg: Springer; 2009. p. 361-72.

106. Baldi A, Srivastava AK, Bisaria VS. Fungal elicitors for enhanced production of secondary metabolites in plant cell suspension cultures. In: Varma A, Kharkwal AC. (ed) Symbiotic fungi. Berlin Heidelberg: Springer; 2009. p. 373-80.

107. Baldi A, Dixit VK. Yield enhancement strategies for artemisinin production by suspension cultures of Artemisia annua. Bioresour Technol 2008;99:4609-14.

108. Baldi A, Singh D, Dixit VK. Dual elicitation for improved production of withaferin A by cell suspension cultures of Withania somnifera. Appl Biochem Biotechnol 2008; 151:556-64. 